\title{
Efficacy and Safety of Bisphosphonate Therapy in Children with Osteogenesis Imperfecta: A Systematic Review
}

Citation for published version (APA):

Rijks, E. B. G., Bongers, B. C., Vlemmix, M. J. G., Boot, A. M., van Dijk, A. T. H., Sakkers, R. J. B., \& van Brussel, M. (2015). Efficacy and Safety of Bisphosphonate Therapy in Children with Osteogenesis Imperfecta: A Systematic Review. Hormone Research in Paediatrics, 84(1), 26-42.

https://doi.org/10.1159/000381713

Document status and date:

Published: 01/01/2015

DOI:

10.1159/000381713

Document Version:

Publisher's PDF, also known as Version of record

\section{Document license:}

Taverne

Please check the document version of this publication:

- A submitted manuscript is the version of the article upon submission and before peer-review. There can be important differences between the submitted version and the official published version of record.

People interested in the research are advised to contact the author for the final version of the publication, or visit the DOI to the publisher's website.

- The final author version and the galley proof are versions of the publication after peer review.

- The final published version features the final layout of the paper including the volume, issue and page numbers.

Link to publication

\footnotetext{
General rights rights.

- You may freely distribute the URL identifying the publication in the public portal. please follow below link for the End User Agreement:

www.umlib.nl/taverne-license

Take down policy

If you believe that this document breaches copyright please contact us at:

repository@maastrichtuniversity.nl

providing details and we will investigate your claim.
}

Copyright and moral rights for the publications made accessible in the public portal are retained by the authors and/or other copyright owners and it is a condition of accessing publications that users recognise and abide by the legal requirements associated with these

- Users may download and print one copy of any publication from the public portal for the purpose of private study or research.

- You may not further distribute the material or use it for any profit-making activity or commercial gain

If the publication is distributed under the terms of Article $25 \mathrm{fa}$ of the Dutch Copyright Act, indicated by the "Taverne" license above, 


\title{
Efficacy and Safety of Bisphosphonate Therapy in Children with Osteogenesis Imperfecta: A Systematic Review
}

\author{
Ester B.G. Rijks ${ }^{a} \quad$ Bart C. Bongers ${ }^{a}$ e Marloes J.G. Vlemmix ${ }^{a}$ d \\ Annemieke M. Boot ${ }^{f}$ Atty T.H. van Dijk ${ }^{b}$ Ralph J.B. Sakkers ${ }^{c}$ \\ Marco van Brussel ${ }^{a}$
}

${ }^{a}$ Child Development \& Exercise Center and Departments of b Pediatrics and ' Orthopedics, Wilhelmina Children's Hospital, and d Clinical Health Sciences, University Medical Center Utrecht, Utrecht, ${ }^{e}$ Department of Epidemiology, School for Public Health and Primary Care (CAPHRI), Maastricht University, Maastricht, and fPediatric Endocrinology Subdivision, Department of Pediatrics, University Medical Center Groningen, University of Groningen, Groningen, The Netherlands

\section{Key Words}

Osteogenesis imperfecta · Child · Bisphosphonates .

Fractures · Bone mineral density

\begin{abstract}
Background/Aims: To systematically assess contemporary knowledge regarding the effectiveness and safety of bisphosphonates (BPs) in children with osteogenesis imperfecta (OI). Methods: PubMed/MEDLINE, Embase, and Cochrane were searched for eligible articles up to June 2014. Studies eligible for inclusion were (randomized) controlled trials assessing the effects of BPs in children with OI. Methodological quality was assessed independently by 4 reviewers using the Cochrane Collaboration's tool for risk of bias. Results: Ten studies (519 children) were included. Four studies (40\%) showed a low risk of bias. All studies investigating lumbar spine areal bone mineral density indicated a significant increase as a result of BP treatment. Most studies observed a significant decrease in fracture incidence. The most
\end{abstract}

(c) 2015 S. Karger AG, Basel

$1663-2818 / 15 / 0841-0026 \$ 39.50 / 0$ frequently reported adverse events were gastrointestinal complaints, fever, and muscle soreness. A significant decrease in (bone) pain due to BP treatment was observed in more than half of the studies. Most studies measuring urinary markers of bone resorption reported a significant decrease. The majority of studies with intravenous treatment showed a significant increase in lumbar projection area, whereas studies with oral treatment did not. Conclusions: Treatment with oral or intravenous BPs in children with OI results in an increase in bone mineral density and seems to be safe and well tolerated.

() 2015 S. Karger AG, Basel

\section{Introduction}

Osteogenesis imperfecta (OI) is a clinically heterogeneous heritable, and most often autosomal dominant, condition characterized by increased bone fragility, predisposing to fractures, a low bone mass, bone deformities, 
and a short stature [1-3]. In addition, children with OI frequently exhibit vertebral compressions, blue sclera, premature hearing loss, dentinogenesis imperfecta, easy bruising, hypermobility, low muscle tone, a reduced exercise capacity, and muscle weakness $[1,2,4-6]$. The exact incidence of OI is unknown; however, it has been estimated at 1 in 10,000-20,000 births [1, 7].

In most cases (90\%), OI is caused by (autosomal dominant) mutations in genes encoding type 1 collagen (COL1A 1 and COL1A2) $[3,8]$. Collagen type 1 is the main structural protein of bone, tendons, ligaments, skin, dentin, and sclera [9]. Recessively inherited forms of OI are caused by mutations in genes encoding proteins involved in posttranslational modification and correct helical folding of type 1 collagen $[2,8]$. However, in some cases OI can also be initiated by mutations in non-collagen-related genes $[2,8]$. Dominantly inherited defects in COL1A1 or COL1A2 result in quantitative deficiencies, qualitative deficiencies in collagen, or a combination of both. Sequentially, an abnormal collagen matrix is synthesized, creating an abnormal bone matrix with increased bone fragility $[1,2]$.

Presently, no definite cure for OI is available and therefore treatment is primarily focused on diminishing its symptoms $[1,10]$ and includes pharmacological treatment, orthopedic surgery, physiotherapy, and rehabilitation. In order to improve bone strength, numerous pharmacological agents have been administered to children with OI in the last decades, including hormones, vitamins, and minerals $[1,11]$. Currently, second- and thirdgeneration (nitrogenous) oral and intravenous bisphosphonates (BPs) are considered standard care for children with OI and particularly for children with moderate and severe forms of OI $[8,12-14]$. Increasing evidence indicates that BPs might be involved in osteoblastogenesis [15] and decelerating bone resorption, which results in an altered balance in remodeling in favor of bone formation [1]. More recent nitrogenous BPs like zoledronate and risedronate have an even greater potency in inhibiting bone resorption than the older nitrogenous BPs like pamidronate and neridronate [16].

Studies regarding the effects of these second- and third-generation BPs (e.g. alendronate, pamidronate, olpadronate, and risedronate) in children with OI suggest improvements in the density of the investigated bones. Furthermore, many of these studies have also demonstrated a reduction in fracture rates and enhanced growth with only a few short-term side effects of the utilized BPs [17-28]. The most frequently observed (short-term) side effects are fever and body aches with the first infusion, as well as hypocalcemia (without serious complications). Though promising, several of these studies are either uncontrolled clinical trials ignoring the normal disease course or have a low methodological quality. Additionally, no international consensus regarding the effectiveness and safety of BPs in the treatment of children with OI is currently available. Vital questions from clinicians regarding the safety and efficacy of clinical administration of BPs therefore remain. These questions include the critical period and optimal duration of treatment with BPs, and the long- and short-term adverse effects of different types of BPs in children with OI. Therefore, the objective of the current review is to systematically assess contemporary knowledge regarding the effectiveness and safety of BPs used in (randomized) controlled trials in children with OI to provide a clear, detailed, and evidence-based overview for clinicians treating children with OI.

\section{Methods}

\section{Search Strategy}

The electronic databases PubMed/MEDLINE, Embase, and Cochrane were searched for eligible articles up to June 2014. The search did not have language restrictions. The following $\mathrm{MeSH}$ terms and keywords were employed: osteogenesis imperfecta, diphosphonates, bisphosphonate, etidronic acid, etidronate, clodronic acid, clodronate, tiludronic acid, tiludronate, pamidronate, 6-amino-1-hydroxyhexane-1,1-diphosphonate, neridronate, olpadronic acid, olpadronate, alendronate, ibandronic acid, ibandronate, risedronic acid, risedronate, zoledronic acid, and zoledronate. The complete search strategy can be found in Appendix 1. Articles were eligible for inclusion if they: (1) were investigating the effects of BPs in children with OI, (2) were conducted as a randomized controlled trial (RCT) or as a nonrandomized controlled trial (CT), and (3) studied $>15$ children with OI. Articles were excluded if they: (1) had a treatment period $<1$ year, (2) used historical matched controls, (3) made a comparison between the effects of different dosages, or (4) made a comparison between the effects of different BPs.

\section{Selection of Studies}

Four independent reviewers (E.B.G.R., B.C.B., M.J.G.V., and M.v.B.) conducted inclusion of eligible articles. Initially, articles were screened for eligibility based on their title and abstract. When the title and abstract implied that an article was potentially eligible for inclusion, a full paper copy of the report was obtained. Disagreements between reviewers regarding an article's eligibility were resolved by discussion until a consensus was reached. Additionally, reference tracking was performed in all included articles (fig. 1).

\section{Data Extraction and Management}

The reviewers extracted data using a standard extraction form. Data extracted from the included articles were: (1) first author and 
Fig. 1. Study selection process.

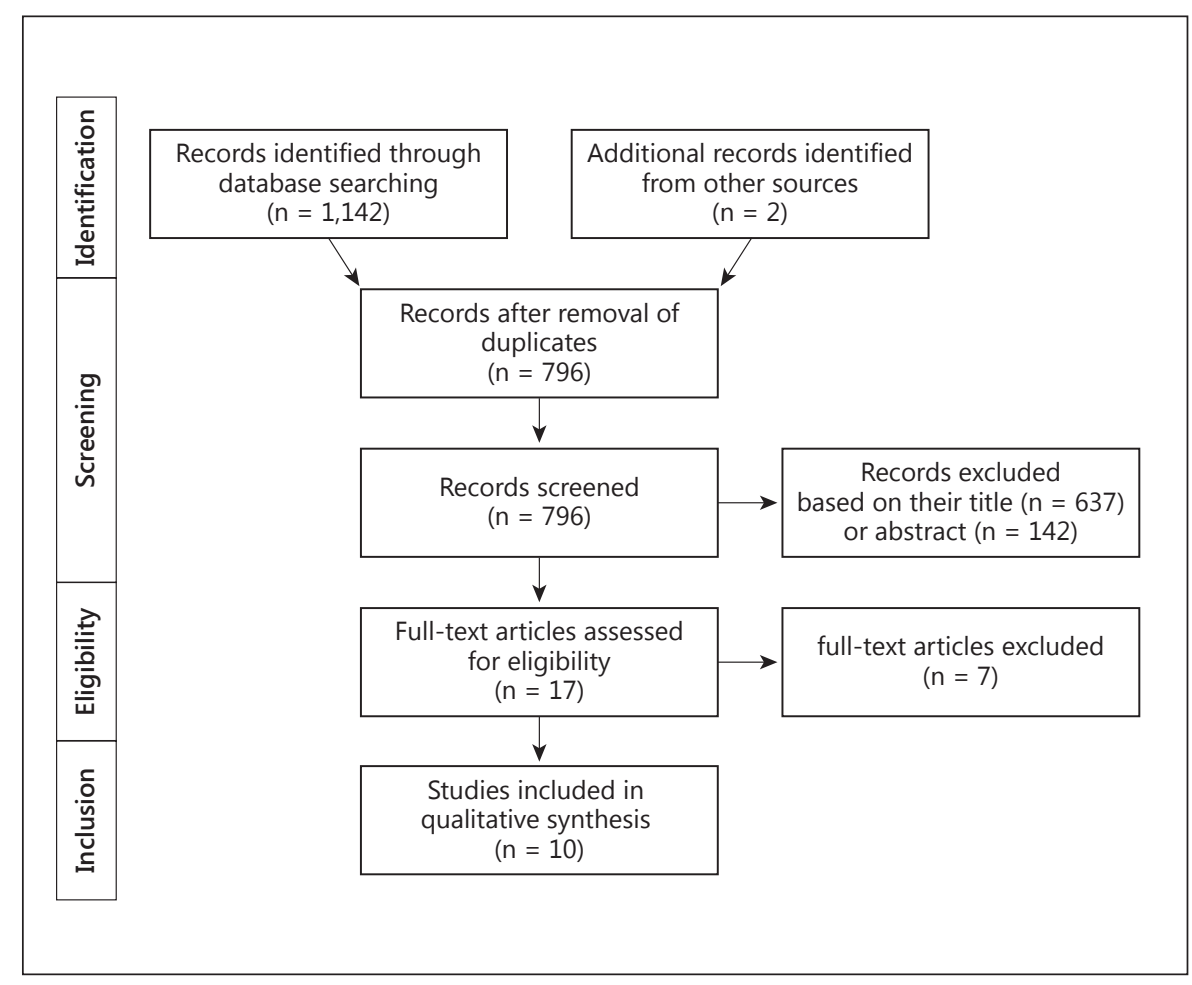

study location; (2) study design; (3) participants; (4) treatment; (5) outcome measurements, and (6) results. If data were missing or further information was required, serious attempts were made to contact the first two authors to request the required information. The results of the data extraction are shown in table 1 .

Assessment of Methodological Quality (Risk of Bias)

Four reviewers independently assessed the methodological validity of the included articles. The methodological quality (risk of bias) was scored using the adapted version of the Cochrane Collaboration's tool. This adapted tool reviews 5 domains, with 11 items in total (table 2). Each item was rated as 'yes', 'no', or 'unsure' and scored with a ' + ' when yes and a '-' when no or unsure. Studies fulfilling 6 or more criteria were regarded as having a low risk of bias $[29,30]$. Disagreements were resolved in a consensus among the 4 raters. The strength of interrater agreement was measured by Cohen's $\kappa$ coefficient $(95 \% \mathrm{CI})$, with $\kappa=0.41-0.60$ indicating moderate agreement, $\kappa=0.61-0.80$ representing good agreement, and $\kappa \geq 0.81$ representing very good agreement $[29,30]$.

\section{Results}

In total, 10 full-text articles (including 519 children) that met the inclusion criteria were identified and reviewed, of which 7 were RCTs $[17,19,20,31-34]$ and 3 were CTs [21, 22, 35] (fig. 1). The efficacy of oral [17, 20, 32-34] and intravenous [19, 21, 22, 31, 35] BPs was ex- amined in 5 studies. Intravenous pamidronate [19, 22], intravenous neridronate $[21,31]$, oral alendronate [20, $34]$, and oral risedronate [32, 33] were all appraised in 2 studies, whereas oral olpadronate [17] and intravenous ibandronate [35] were both investigated in 1 study. This review evaluates the following outcome measures of the included studies: areal bone mineral density $(\mathrm{aBMD})^{1}$, fracture incidence, adverse effects, (bone) pain, urinary markers of bone resorption, and projection area $^{2}$. The included studies also describe the effects of BPs on functional outcome measures such as height, weight, muscle strength, ambulation, mobility, and self-care; however, these outcomes will be described in a separate review due to the quantity of the outcome measures. The results of outcome measures were clustered on type of BP to provide a clear overview. Statistical pooling of the results for performing meta-analyses was not feasible due to diversity in outcome expression and missing absolute data. Moreover, most authors of the included studies did not send the required data for pooling after having been contacted.

aBMD is the bone mineral density result given by the DXA measurement. Lumbar spine projection area relates to the size of the vertebrae.
Rijks/Bongers/Vlemmix/Boot/van Dijk/ Sakkers/van Brussel 
Table 1. Characteristics of the included studies

\begin{tabular}{|c|c|c|c|c|}
\hline $\begin{array}{l}\text { First author } \\
\text { [Ref.], location }\end{array}$ & $\begin{array}{l}\text { Study } \\
\text { design }\end{array}$ & $\begin{array}{l}\text { Patients/controls }{ }^{\mathrm{a}} \text {; } \\
\text { OI type(s); } \\
\text { age at baseline }{ }^{\mathrm{b}}\end{array}$ & Treatment/intervention & Outcome measures \\
\hline $\begin{array}{l}\text { Sakkers [17], } \\
\text { Wilhelmina } \\
\text { Children's } \\
\text { Hospital } \\
\text { (Utrecht, The } \\
\text { Netherlands) }\end{array}$ & RCT & $\begin{array}{l}34(\mathrm{I}: \mathrm{n}=16 \\
\text { P: } \mathrm{n}=18) \\
\text { I, III, and IV; } \\
\text { I: } 10.0 \pm 3.1 \\
\text { P: } 10.7 \pm 3.9 \text { years }\end{array}$ & $\begin{array}{l}\text { I: oral olpadronate } \\
\left(10 \mathrm{mg} / \mathrm{m}^{2} / \text { day }\right) \text { for } \\
2 \text { years } \\
\text { P: enteric coated placebo } \\
\text { tablets } \\
\text { All children received } \\
\text { additional calcium and } \\
\text { vitamin D }\end{array}$ & $\begin{array}{l}\text { Primary: } \\
\text { - Incident fractures of } \\
\text { long bones } \\
\text { - Changes in BMC } \\
\text { - Changes in BMD } \\
\text { - Functional outcome } \\
\text { Secondary: } \\
\text { - Anthropometry } \\
\text { - Vertebral height } \\
\text { - Urinary markers of } \\
\text { bone resorption }\end{array}$ \\
\hline
\end{tabular}

Results

- aBMD: The increase in lumbar spine aBMD with oral olpadronate was significantly greater compared to placebo. At baseline, the lumbar spine aBMD was $0.31 \pm 0.16 \mathrm{~g} / \mathrm{cm}^{2}$ in the olpadronate group and $0.32 \pm 0.14 \mathrm{~g} /$ $\mathrm{cm}^{2}$ in the placebo group. After 2 years of treatment, the adjusted annual difference in lumbar spine aBMD was $0.054 \mathrm{~g} / \mathrm{cm}^{2}(95 \% \mathrm{CI}$ $0.012-0.096 ; \mathrm{p}=0.010)$. Spinal $\mathrm{z}$-scores increased from -4.98 to -3.31 in the olpadronate group and from -4.84 to -4.70 in the placebo group after 2 years of treatment. The adjusted group difference in lumbar spine aBMD was 0.74 (95\% CI 0.29-1.19; $\mathrm{p}=0.002$ ).

- Fracture incidence: There was a reduction of $31 \%$ in the relative fracture risk of long bones after 2 years of treatment with oral olpradronate (HR 0.69; 95\% CI 0.52-0.91; $\mathrm{p}=0.010$ ). The total number of fractures was 18 in 16 patients in the olpadronate group and 50 in 18 patients in the placebo group.

- Adverse events: There were no acute phase reactions or adverse events after oral olpadronate use.

- uNTx: there were no significant differences within or between groups in urinary C-telopeptides/creatinine and D-deoxypyridinolines/ creatinine [difference -114.5 (95\% CI -281.2 to -52.3$)$ and -1.98 (95\% CI -6.56 to -2.60$) ; \mathrm{p}=0.190$ and $\mathrm{p}=0.400$, respectively] after 2 years of oral olpadronate or placebo. No differences between groups in changes in urinary markers of bone resorption were found.

\begin{tabular}{|c|c|c|c|c|}
\hline $\begin{array}{l}\text { Ward [34], } \\
\text { Shriners } \\
\text { Hospital for } \\
\text { Children } \\
\text { (Montreal, } \\
\text { Canada) }\end{array}$ & RCT & $\begin{array}{l}139(\mathrm{I}: \mathrm{n}=109 \\
\text { P: } \mathrm{n}=30) \\
\text { I, III, and } \mathrm{IV} \\
\text { I: } 11.0 \pm 3.6 \\
\text { P: } 11.1 \pm 4.0 \text { years }\end{array}$ & $\begin{array}{l}\text { I: oral alendronate } \\
(5 \mathrm{mg} / \text { day in children } \\
<40 \mathrm{~kg} \text { and } 10 \mathrm{mg} / \text { day in } \\
\text { children }>40 \mathrm{~kg} \text { ) for } 2 \\
\text { years } \\
\text { P: matching placebo. All } \\
\text { children were advised to } \\
\text { meet the age-related } \\
\text { dietary reference intake } \\
\text { for calcium and } \\
\text { vitamin D }\end{array}$ & $\begin{array}{l}\text { Primary: } \\
\text { - Spine aBMD z-score } \\
\text { - uNTx } \\
\text { - Extremity fracture } \\
\text { incidence } \\
\text { - Vertebral area } \\
\text { - Iliac cortical width } \\
\text { - Bone pain } \\
\text { - Physical activity } \\
\text { - Safety parameters }\end{array}$ \\
\hline
\end{tabular}

- aBMD: the spinal aBMD increased significantly with oral alendronate [ $p<0.001$; mean change in $\mathrm{z}$-score $+1.32(95 \%$ CI $1.08-1.56) /+50.7 \%$ (95\% CI 38.0-63.4)] compared to placebo [mean change in z-score $+0.14(95 \% \mathrm{CI}-0.21$ to 0.48$) /+11.9 \%(95 \% \mathrm{CI}-6.4$ to 30.2$)]$ after 2 years of treatment. The mean spine aBMD z-score increased significantly in the alendronate group from -4.6 to -3.3 ( $\mathrm{p}<0.001$; the change in placebo group was insignificant, i.e. from -4.6 to -4.5 ).

- Fracture incidence: the long-bone fracture incidence was similar between groups. A relative risk of 1.04 (95\% CI 0.81-1.34) of having $\geq 1$ new long-bone fracture for the oral alendronate group $(p>0.05)$ was reported. The number of patients with $\geq 1$ long-bone fracture was 71 $(75 \%)$ in the alendronate group $(\mathrm{n}=95)$ and $21(72 \%)$ in the placebo group $(\mathrm{n}=29)$.

- Adverse events: the incidence of clinical and laboratory adverse experiences was similar between groups. Gastrointestinal complaints were the most reported adverse events, but their occurrence was not significantly different between the oral alendronate and placebo groups $(\mathrm{p}=0.836)$. Only abdominal pain and vomiting were attributed to alendronate.

- Bone pain: bone pain was similar between groups. In the oral alendronate group, significantly fewer patients with bone pain were found at 24 months compared to baseline $(p<0.001)$; however, compared to controls, the difference in the percentage of patients with bone pain at 24 months was not significant $(\mathrm{p}=0.065)$. Furthermore, no significant difference was observed in the number of days per week during which patients suffered bone pain $(p=0.167)$.

- uNTx: uNTx levels decreased significantly $(\mathrm{p}<0.001)$ more in the oral alendronate group than in the control group after 24 months [mean change $-62.2 \%(95 \% \mathrm{CI}-67.4$ to -56.1$)$ and $-32.0 \%$ (95\% CI -46.7 to $-13.3)$, respectively]. In the alendronate group uNTX decreased from 131 to $63 \%$ of the healthy average, and in the control group uNTX decreased from 128 to $112 \%$ (95\% CI for the difference in change -87 to $-15 ; \mathrm{p}=0.006$ ).

- Projection area: the increase in lumbar spine area in the oral alendronate group was not significantly different compared to placebo after 2 years [mean change $14.2 \%$ (95\% CI 10.4-18.0) and $12.2 \%(95 \%$ CI 6.7-17.6), respectively; $\mathrm{p}=0.493$ ]. 
Table 1 (continued)

\begin{tabular}{|c|c|c|c|c|}
\hline $\begin{array}{l}\text { First author } \\
\text { [Ref.], location }\end{array}$ & $\begin{array}{l}\text { Study } \\
\text { design }\end{array}$ & $\begin{array}{l}\text { Patients/controls }{ }^{\mathrm{a}} \text {; } \\
\text { OI type(s); } \\
\text { age at baseline }{ }^{\mathrm{b}}\end{array}$ & Treatment/intervention & Outcome measures \\
\hline $\begin{array}{l}\text { Seikaly [20], } \\
\text { Texas Scottish } \\
\text { Rite Hospital } \\
\text { for Children } \\
\text { (Dallas, Tex., } \\
\text { USA) }\end{array}$ & $\begin{array}{l}\text { RCT } \\
\text { (cross- } \\
\text { over) }\end{array}$ & $\begin{array}{l}17 ; \\
\text { I, III, and IV; } \\
9.0 \pm 1.06 \text { years }\end{array}$ & $\begin{array}{l}\text { I: oral alendronate } \\
(5 \mathrm{mg} / \text { day in children } \\
<30 \mathrm{~kg} \text { and } 10 \mathrm{mg} / \text { day } \\
\text { in children }>30 \mathrm{~kg} \text { ) for } \\
1 \text { year } \\
\text { P: placebo treatment not } \\
\text { further specified } \\
\text { All subjects were } \\
\text { maintained on a diet } \\
\text { with adequate daily } \\
\text { calcium }(1,000-1,300 \\
\mathrm{mg} / \text { day), phosphorus } \\
(800-1,200 \mathrm{mg} / \text { day }) \text {, and } \\
\text { vitamin D }(400 \mathrm{IU} / \text { day }) \\
\text { intake, at least } 100 \% \text { of } \\
\text { the daily referenced } \\
\text { intake }\end{array}$ & $\begin{array}{l}\text { Primary: } \\
\text { - BMD } \\
\text { - Quality of life } \\
\text { [total mobility (PEDI), } \\
\text { self-care (WeeFIM), } \\
\text { well-being, pain, and } \\
\text { use of analgesic scores] } \\
\text { Secondary: } \\
\text { - Biochemical } \\
\text { parameters [changes in } \\
\text { the complete blood } \\
\text { count or levels of } \\
\text { serum creatinine, } \\
\text { electrolytes, fasting } \\
\text { serum phosphorus, } \\
\text { serum calcium, SGPT, } \\
\text { alkaline phosphatase, } \\
\text { osteocalcin, intact } \\
\text { PTH, or 1,25(OH)2 } \\
\text { vitamin D] } \\
\text { - Urinary indices } \\
\text { (creatinine clearance, } \\
\text { urinary calcium, } \\
\text { hydroxyproline } \\
\text { excretions, uNTX/uCr, } \\
\text { nephrocalcinosis) } \\
\text { - Changes in height and } \\
\text { BMI } \\
\text { - Rate of skeletal } \\
\text { fractures } \\
\text { - Adverse reactions }\end{array}$ \\
\hline
\end{tabular}

\begin{tabular}{|c|c|c|c|c|}
\hline $\begin{array}{l}\text { Rauch [33], } \\
\text { Shriners } \\
\text { Hospital for } \\
\text { Children } \\
\text { (Montreal, } \\
\text { Canada) }\end{array}$ & RCT & $\begin{array}{l}26(\mathrm{I}: \mathrm{n}=13 \\
\text { P: } \mathrm{n}=13) \\
\text { I; } \mathrm{I}: 11.7 \pm 3.6 \\
\text { P: } 11.9 \pm 4.0 \text { years }\end{array}$ & $\begin{array}{l}\text { I: oral risedronate } \\
(15 \mathrm{mg} / \text { week in children } \\
<40 \mathrm{~kg} \text { and } 30 \mathrm{mg} / \text { week } \\
\text { in children }>40 \mathrm{~kg}) \text { for } \\
2 \text { years } \\
\text { P: matching placebo, } \\
\text { not further specified } \\
\text { All patients received } \\
\text { supplemental calcium } \\
\text { and vitamin D as part of } \\
\text { standard care if the daily } \\
\text { intake was }<800 \text { mg or } \\
400 \text { IU }\end{array}$ & $\begin{array}{l}\text { Primary: } \\
\text { - Change in lumbar } \\
\text { spine } \\
\text { - aBMD z-score } \\
\text { Secondary: } \\
\text { - Cortical width at the } \\
\text { midpoint of the second } \\
\text { metacarpal } \\
\text { - Change in the cortical } \\
\text { width of iliac bone } \\
\text { - Number of } \\
\text { radiologically } \\
\text { confirmed fractures }\end{array}$ \\
\hline
\end{tabular}

Results

- aBMD: a significant increase $(\mathrm{p}<0.001)$ in lumbar spine aBMD with oral alendronate treatment (mean change in $\mathrm{z}$-score $+0.89 \pm 0.19$ ) compared to placebo (mean change in $\mathrm{z}$-score $-0.12 \pm 0.14$ ) after 1 year of treatment was reported. BMD improved from a change in SD score (z-score) of $0.89 \pm 0.19$ to $-0.12 \pm 0.14$.

- Fracture incidence: 3 fractures occurred in the oral alendronate group $(\mathrm{n}=10)$ and 9 fractures occurred in the placebo group $(\mathrm{n}=10)$ during 1 year of BP treatment.

- Adverse events: daily alendronate was well tolerated. Only 2 patients had mild gastrointestinal discomfort, responding to minor adjustments in alendronate intake.

- Bone pain: a significant decrease $(\mathrm{p}<0.001)$ in pain score (in days/ week) after oral alendronate treatment (mean change $-3.13 \pm 0.63$ ) compared to placebo (mean change $0.50 \pm 0.47$ ) was observed after 1 year of treatment.

- uNTX: uNTX/uCR was decreased by $56 \%$ in the treatment group after 1 year of oral alendronate $(541 \pm 64$ to $244 \pm 60 \rho \mathrm{mol} / \mu \mathrm{mol} \mathrm{Cr} ; \mathrm{p}<0.010)$ The control group showed no significant effects.

- aBMD: a significantly greater increase in lumbar spine aBMD was observed with oral risedronate $(+23.8 \% \pm 15.4)$ compared to placebo $(+6.8 \% \pm 10.6)$ after 2 years $(\mathrm{p}=0.003)$. The $\mathrm{z}$-scores of lumbar spine aBMD at baseline were $-2.97 \pm 0.97$ and $-2.66 \pm 0.86$ in the treatment and placebo groups, respectively. After 2 years of treatment, the z-scores of lumbar spine $\mathrm{aBMD}$ increased significantly more with risedronate $(+0.65 \pm 0.65)$ compared to placebo $(-0.15 \pm 0.39 ; \mathrm{p}=0.002)$. No significant change in hip aBMD was observed after 2 years of treatment with oral risedronate compared to placebo (mean change $12.4 \pm 10.8$ and $6.5 \pm 5.9 \%$, respectively; $\mathrm{p}=0.110$ ). The increase in total body aBMD with oral risedronate after 2 years was not significantly different compared to placebo (change $10.7 \pm 7.1$ and $6.5 \pm 4.6 \%$, respectively; $\mathrm{p}=$ 0.090).

- Fracture incidence: no significant differences in the number of fractures during 2 years of BP therapy with risedronate or placebo were found. In both the intervention group and control group 11 fractures occurred ( $\mathrm{n}=13$ in both groups).

- Adverse events: the incidence of clinical or laboratory adverse experiences was similar among treatment groups. All patients had at least one adverse event. The number of patients with gastrointestinal complaints did not differ statistically between groups $(\mathrm{p}=0.420)$.

- Bone pain: there was no detectable treatment effect on bone pain. Two patients in the risedronate group and 8 patients in the control group experienced bone pain at baseline, and after 2 years of treatment 4 patients in each group suffered from bone pain.

- uNTX: no significant difference in $\mathrm{UNTx} / \mathrm{uCr}$ ratios was reported (change $-27.7 \pm 33.6$ and $-10.7 \pm+43.7 \%$, respectively; $p=0.280$ ) after 2 years of oral risedronate compared to placebo, but in serum NTx a significant decrease was reported (change $-34.6+22.2$ and $-6.2+39.0 \%$, respectively; $\mathrm{p}=0.030$ ).

- Projection area: the increase in lumbar spine area in the oral risedronate group was not significant compared to placebo after 2 years (change 16.4 \pm 13.8 and $10.2 \pm 11.6 \%$, respectively; $\mathrm{p}=0.230$ ). 
Table 1 (continued)

\begin{tabular}{|c|c|c|c|c|}
\hline $\begin{array}{l}\text { First author } \\
\text { [Ref.], location }\end{array}$ & $\begin{array}{l}\text { Study } \\
\text { design }\end{array}$ & $\begin{array}{l}\text { Patients/controls }{ }^{\mathrm{a}} \text {; } \\
\text { OI type(s); } \\
\text { age at baseline }{ }^{\mathrm{b}}\end{array}$ & Treatment/intervention & Outcome measures \\
\hline $\begin{array}{l}\text { Letocha [19], } \\
\text { National } \\
\text { Institute of } \\
\text { Child Health } \\
\text { and Human } \\
\text { Development } \\
\text { (NICHD; } \\
\text { Bethesda, Md., } \\
\text { USA) }\end{array}$ & RCT & $\begin{array}{l}18(\mathrm{I}: \mathrm{n}=9, \mathrm{P}: \\
\mathrm{n}=9) ; \\
\mathrm{III} \text { and } \mathrm{IV} ; \\
\text { I: } 11.05 \pm 2.4 \\
\mathrm{P}: 9.97 \pm 3.1 \text { years }\end{array}$ & $\begin{array}{l}\text { I: intravenous } \\
\text { pamidronate }(10 \mathrm{mg} / \\
\mathrm{m}^{2} / \text { day for } 3 \text { days every } \\
3 \text { months) for } 1 \text { year } \\
\text { P: treatment of control } \\
\text { group not further } \\
\text { specified } \\
\text { Four children in each } \\
\text { group also received } \\
\text { recombinant growth } \\
\text { hormone injections } \\
(0.06 \mathrm{mg} / \mathrm{kg} / \text { day, } 6 \text { days/ } \\
\text { week), and } 7 \text { children in } \\
\text { the treatment group } \\
\text { received pamidronate for } \\
\text { an additional } 6-21 \\
\text { months. Patients }<10 \\
\text { years of age received } \\
500 \mathrm{ml} / \text { day calcium } \\
\text { supplementation; } \\
\text { patients }>10 \text { years of age } \\
\text { received } 1,000 \mathrm{mg} / \text { day }\end{array}$ & $\begin{array}{l}\text { Primary: } \\
\text { - Vertebral DXA z-score } \\
\text { - Height } \\
\text { - Area } \\
\text { Secondary: } \\
\text { - Functional measures: } \\
\quad \text { gross motor function, } \\
\text { muscle strength, and } \\
\text { pain }\end{array}$ \\
\hline
\end{tabular}

Results

\begin{tabular}{|c|c|c|c|c|}
\hline $\begin{array}{l}\text { Gatti [18], } \\
\text { Italian } \\
\text { Association of } \\
\text { Patients with } \\
\text { OI (AsItOI; } \\
\text { Verona, Italy) }\end{array}$ & RCT & $\begin{array}{l}64(\mathrm{I}: \mathrm{n}=42 \\
\text { P: } \mathrm{n}=22) \\
\mathrm{I}, \mathrm{III} \text {, and } \mathrm{IV} \\
\text { I: } 8.6 \pm 2.4 \\
\text { P: } 9.0 \pm 2.3 \text { years }\end{array}$ & $\begin{array}{l}\text { I: intravenous } \\
\text { neridronate }(2 \mathrm{mg} / \mathrm{kg} \\
\text { every } 3 \text { months) for } 3 \\
\text { years ( } 1 \text { year controlled) } \\
\text { P: no treatment } \\
\text { Control patients were } \\
\text { given the same BP } \\
\text { therapy at the end of the } \\
\text { first year. Calcium intake } \\
\text { was regularly evaluated } \\
\text { in all patients and } \\
\text { maintained above } 600, \\
800 \text { and } 1,000 \text { mg daily } \\
\text { according to their age: }\end{array}$ & $\begin{array}{l}\text { Primary: } \\
\text { - BMD and projected } \\
\text { bone areas, as } \\
\text { measured by DXA, at } \\
\text { the spine and hip } \\
\text { - Height } \\
\text { - Peripheral fracture } \\
\text { incidence } \\
\text { Measured both } \\
\text { prospectively and } \\
\text { retrospectively ( } 2 \text { years } \\
\text { preceding } \\
\text { randomization) }\end{array}$ \\
\hline
\end{tabular}

- aBMD: lumbar spine aBMD z-scores increased significantly more $(\mathrm{p}<$ 0.001 ) with intravenous pamidronate (from $-5.44 \pm 1.46$ to $-4.04 \pm 1.48$; $\mathrm{p}<0.001$ ) than with placebo (from $-5.74 \pm 0.78$ to $-5.77 \pm 0.90 ; \mathrm{p}=$ 0.880 ) after 1 year of treatment. However, $\mathrm{z}$-scores did not further increase during the second year of treatment in the pamidronate group $(\mathrm{p}<0.001)$.

- Fracture incidence: the fracture rate decreased significantly in the upper extremities $(p=0.04)$ but not the lower extremities $(p=0.09)$ during the first year of treatment. After 2 years of treatment, the fracture rate did not decrease further in the upper extremities $(\mathrm{p}=0.840)$ or in the lower extremities $(\mathrm{p}=0.290)$.

- Adverse events: all treated children experienced acute-phase reactions with the first infusion cycle. No other complications were noted.

- Bone pain: pain did not change significantly during the controlled or extended treatment phases; pain scores changed from $3.75 \pm 0.71$ to $3.44 \pm 0.82(\mathrm{p}=0.300)$ and from $3.94 \pm 0.18$ to $3.55 \pm 0.73(\mathrm{p}=0.170)$ in the pamidronate and control groups after 1 year of treatment.

- Projection area: in the controlled phase, treated patients experienced a significant increase in total vertebral area $(\mathrm{p}=0.003)$. A significant change in the radiologically defined summed L1 to L4 vertebral area after 1 year of pamidronate $\left(1.35 \pm 0.95\right.$ to $\left.1.74 \pm 0.99 \mathrm{~cm}^{2} ; \mathrm{p}=0.006\right)$ was shown. After the second year (extended treatment period, 6-21 months), the vertebral area still increased, but this increase was not significant $\left(1.76 \pm 0.59 \mathrm{~cm}^{2} ; \mathrm{p}=0.110\right)$. Compared to placebo, the summed L1 to L4 vertebral area increased significantly more after 1 year of pamidronate $(\mathrm{p}=0.005)$. Because vertebrae T12, L1, and L2 were most likely to experience compressions from weight bearing, these were also examined. The L2 vertebral area increased significantly more in the treatment group compared to placebo $(p=0.020)$. In the second year of treatment (extended treatment period), the L2 vertebral area did not increase further $(\mathrm{p}=0.0340)$. The T12 to L2 vertebral area in the pamidronate group also increased significantly more after 1 year of pamidronate compared to placebo $(\mathrm{p}=0.050)$, but during the extended treatment period the T12 to L2 vertebral area did not increase significantly $(p=0.0250)$. The vertebral area of T12 and L1 showed no significant difference in rate of increase between groups during the first year $(\mathrm{p}=0.130$ and $\mathrm{p}=0.710$, respectively).

- aBMD: at the end of the first year, spine and hip BMD rose by $3.5-5.7 \%$ in control patients and by $18-25 \%$ ( $p<0.001$ vs. controls) in the active group, respectively. The treatment in both groups was associated with BMD changes in the spine of $~ 30 \%$ during the first year, $20 \%$ during the second year, and 15\% during the third year of treatment. The corresponding changes in the femoral neck and total hip were 18-25, $13-15$, and $7-8 \%$, respectively (all highly significant vs. both baseline and the previous year). The spine $\mathrm{z}$-score did not change in the control group during the first year but rose gradually from -3.39 to -2.01 ( $\mathrm{p}<$ 0.001 ) in the active group over 3 years.

- Fracture incidence: during the first year of treatment, $45 \%$ of the control patients and $27 \%$ of the active group had a nonvertebral fracture, but this difference was not statistically significant $(\mathrm{p}=0.2)$. The total number of fractures was 18 in the 22 control patients and 13 in the active group ( 42 patients) (relative risk 0.36 ; $95 \%$ CI $0.15-0.87$; $\mathrm{p}<0.05)$.

$<7,7-10$, and $>10$ years of age, respectively. If the serum $25(\mathrm{OH})$ vitamin $\mathrm{D}$ levels fell below $20 \mathrm{ng} / \mathrm{ml}$, vitamin D supplements were given (50.000 u monthly). Supplementation was only necessary in four patients.

- Adverse events: 10 of the patients complained of flu-like symptoms, resembling a typical acute-phase reaction, $24-36 \mathrm{~h}$ after the first intravenous infusion, which lasted $<36 \mathrm{~h}$. An attenuated response was also noted by all of them after the second infusion. None of the patients complained of other typical side effects.

- Projection area: the DXA-derived projected area of lumbar spine rose during the first year of observation significantly more in the active group than in the control group $(2.0$ vs. $6.7 \% ; \mathrm{p}<0.05)$. The spine projected area continued to rise in the treated patients toward levels found in healthy individuals. The mean percent increase in the projected area of the lumbar spine of the intravenous neridronate group after 1 year $(6.68 \pm 8.1 \% ; \mathrm{p}<0.010$ vs. baseline $)$ was significantly higher $(\mathrm{p}<0.05)$ compared to the control group $(1.97 \pm 3.3 \%)$. In the subsequent 2 years, both groups showed a significant increase compared to baseline $(\mathrm{p}<0.010)$; however, between groups no significant difference was observed $(12.87 \pm 5.99$ and $14.18 \pm 4.24 \%$ for the intervention group and the control group, respectively). 
Table 1 (continued)

\begin{tabular}{|c|c|c|c|c|}
\hline $\begin{array}{l}\text { First author } \\
\text { [Ref.], location }\end{array}$ & $\begin{array}{l}\text { Study } \\
\text { design }\end{array}$ & $\begin{array}{l}\text { Patients/controls }{ }^{\mathrm{a}} \text {; } \\
\text { OI type(s); } \\
\text { age at baseline }{ }^{\mathrm{b}}\end{array}$ & Treatment/intervention & Outcome measures \\
\hline $\begin{array}{l}\text { Rauch [22], } \\
\text { Shriners } \\
\text { Hospital for } \\
\text { Children } \\
\text { (Montreal, } \\
\text { Canada) }\end{array}$ & $\begin{array}{l}\text { (1) CT } \\
\text { (2) OS }\end{array}$ & $\begin{array}{l}\text { CT: } 24 \text { (I: } \mathrm{n}=12 \text {, } \\
\text { C: } \mathrm{n}=12) \text { matched } \\
\text { for age, OI } \\
\text { severity, and } \\
\text { duration of } \\
\text { pamidronate } \\
\text { treatment } \\
\text { OS: } 38 \text { ( } \mathrm{n}=2 \\
\text { restarted } \\
\text { pamidronate } \\
\text { treatment after } \\
15 \text { and } 16 \text { months } \\
\text { due to feeling } \\
\text { unwell and a lack } \\
\text { stamina); } \\
\text { I, III, IV; } \\
\text { CT: I: } 9.8 \pm 4.2 \text {, } \\
\text { C: } 9.5 \pm 4.2 \\
\text { OS: } \mathrm{I}: 15.5 \pm 4.4 \text {, } \\
\text { C: } 15.6 \pm 4.0 \text { years }\end{array}$ & $\begin{array}{l}\text { I: discontinuation of } \\
\text { intravenous pamidronate } \\
\text { treatment for } 2 \text { years } \\
\text { C: Intravenous } \\
\text { pamidronate on } 3 \\
\text { consecutive days, timing } \\
\text { and dosage of these } \\
\text { 3-day cycles varied with } \\
\text { age, but the yearly dose } \\
\text { remained at } 9 \mathrm{ml} / \mathrm{kg} \text {; } \\
\text { treatment was for } 2 \\
\text { years. Calcium intake } \\
\text { was maintained } \\
\text { adequately according to } \\
\text { the daily recommended } \\
\text { allowance }\end{array}$ & $\begin{array}{l}\text { Primary: } \\
\text { - Lumbar spine bone } \\
\text { mineral content and } \\
\text { aBMD } \\
\text { - Biochemical markers } \\
\text { of bone metabolism } \\
\text { - Fracture incidence } \\
\text { - Clinical evaluation }\end{array}$ \\
\hline
\end{tabular}

Results

- aBMD: the change in lumbar spine aBMD (in $\mathrm{g} / \mathrm{cm}^{2}$ ) after 2 years in the group that continued intravenous pamidronate treatment was not different from the change in lumbar spine aBMD (in $\mathrm{g} / \mathrm{cm}^{2}$ ) in the group that discontinued treatment (mean change $+0.05 \pm 0.07$ and $+0.01 \pm 0.03 \mathrm{~g} / \mathrm{cm}^{2}$, respectively; $\mathrm{p}=0.070$ ). The change in lumbar spine aBMD z-score was significantly different between the groups (mean change $+0.2 \pm 0.7$ and $-0.4 \pm 0.4$ in the group that continued therapy and the group that discontinued therapy, respectively; $\mathrm{p}=0.010$ ).

- Fracture incidence: The total number of long-bone fractures was 13 in the discontinuation group and 6 in the group still receiving pamidronate, but this was not statistically significant $(\mathrm{p}=0.48)$.

- Adverse events: 2 patients who stopped intravenous pamidronate treatment began to feel unwell and lacked stamina. Therefore, treatment was resumed 15 and 16 months after cessation. Two weeks later these symptoms disappeared.

- uNTX: bone resorption activity was higher after treatment discontinuation. uNTx/uCr ratios changed significantly after discontinuation or continuation of pamidronate therapy for 2 years, both in absolute values $(\mathrm{nmol} / \mathrm{mmol})$ and in percentages of age- and sex-specific reference means; $p=0.020$ and $p=0.008$, respectively. Two years after discontinuation of intravenous pamidronate, $\mathrm{uNTx} / \mathrm{uCr}$ ratios increased $(+36 \pm 87 \mathrm{nmol} / \mathrm{mmol},+22 \pm 28 \%)$, and 2 years after continuation of intravenous pamidronate, $\mathrm{uNTX} / \mathrm{uCr}$ ratios decreased $(-54 \pm 86 \mathrm{nmol} / \mathrm{mmol},-12 \pm 30 \%)$.

- Projection area: no significantly different increase in lumbar spine area was observed between the group that discontinued and the group that continued pamidronate treatment after 2 years (change $2.2 \pm 2.9$ and $2.9 \pm 5.8 \mathrm{~cm}^{2}$, respectively; $\mathrm{p}=0.720$ )

\begin{tabular}{lll}
\hline Li [35], Peking & CT & $30(\mathrm{I}: \mathrm{n}=20$, \\
Union Medical & & C: $\mathrm{n}=10) ;$ \\
College & I, III, IV, and V; \\
Hospital & I: $10.6 \pm 5.1$, \\
(PUMCH; & C: $7.9 \pm 4.9$ years \\
Beijing, China) &
\end{tabular}

\begin{tabular}{|c|c|}
\hline $\begin{array}{l}\text { I: intravenous } \\
\text { ibandronate in a dosage } \\
\text { of } 2 \text { mg diluted in } 250 \mathrm{ml} \\
\text { isotonic saline, } \\
\text { administered over } 2 \mathrm{~h} \\
\text { once every } 3 \text { months for } \\
24 \text { months } \\
\text { C: } 0.25 \mu \mathrm{g} \text { calcitriol daily } \\
\text { ( = placebo) } \\
\text { All patients received } \\
\text { CalciChew-D daily } \\
\text { which contains } \\
\text { elemental calcium } \\
500 \text { mg and vitamin } \mathrm{D}_{3} \\
(200 \mathrm{U})\end{array}$ & $\begin{array}{l}\text { Primary: } \\
\text { - Change in the annual } \\
\text { new bone fracture rate } \\
\text { and BMD } \\
\text { - Change in bone } \\
\text { turnover markers } \\
\text { (CTX and ALP; CTX = } \\
\text { bone resorption } \\
\text { marker, ALP = bone } \\
\text { formation marker) and } \\
\text { vertebral shape } \\
\text { Secondary: } \\
\text { - Safety }\end{array}$ \\
\hline
\end{tabular}

- aBMD: BMD increased significantly at the lumbar spine, femoral neck, trochanter, and total hip by $59.0,42.0,47.5$, and $36.6 \%$ in a timedependent manner (compared to baseline; $\mathrm{p}<0.001$ ). This increase was greater than in the calcitriol group $(\mathrm{p}<0.001 ; 24.6,29.9,30.6$, and $26.9 \%$, compared to baseline; $\mathrm{p}<0.05)$.

Beijing, China)

I: $10.6 \pm 5.1$

- Fracture incidence: the annual new fracture rate was significantly decreased from 1.9 to 0.13 ( $\mathrm{p}<0.001$ ), obviously lower than that of the calcitriol group, which decreased from 1.8 to $1.0(\mathrm{p}>0.05)$ after the treatment. Five new fragile fractures occurred in 5 cases during treatment with ibandronate, and 20 new fragile fractures were found in 8 cases during treatment with calcitriol.

- Adverse events: children tolerated ibandronate quite well. Mild fever and muscle pain were found in 9 cases within 1-3 days after the first infusion, which could be relieved after 1-2 days without special management. Fever with muscle soreness was found in 13 (65.0\%) patients within 2-3 days of the first infusions of ibandronate. The maximum body temperature was $38.5^{\circ} \mathrm{C}$. After subsequent infusions these symptoms did not recur. No obvious side effects were found in the control group. No delayed fracture healing was found during treatment or control. No osteonecrosis of the jaw occurred.

\begin{tabular}{|c|c|c|}
\hline $\begin{array}{l}\text { Antoniazzi } \\
{[21], \text { Pediatric }} \\
\text { Clinic and } \\
\text { Rheuma- } \\
\text { tological } \\
\text { Rehabilitation } \\
\text { (Verona, Italy) }\end{array}$ & CT & $\begin{array}{l}20 \text { [I: } \mathrm{n}=10 \text { ( } 5 \mathrm{in} \\
\text { group A and } 5 \text { in } \\
\text { group B), C: } \mathrm{n}=10 \\
\text { (group C), } \\
\text { historical matched } \\
\text { control group]; } \\
\text { III; I: } 0.10 \pm 0.02 \\
\text { (A) and } 0.60 \pm 0.04 \\
\text { years (B), C: NA } \\
\text { (matched for sex, } \\
\text { age and clinical } \\
\text { severity of OI) }\end{array}$ \\
\hline
\end{tabular}

$\begin{array}{ll}\text { I: intravenous } & \text { Clinical data: } \\ \text { neridronate at 2 mg/kg } & \text { - Weight } \\ \text { of body weight every 3 } & \text { - Length } \\ \text { months } & \text { - Number of fractures } \\ \text { Group A started } & \text { - Side effects } \\ \text { treatment just after } & \text { Laboratory data: } \\ \text { diagnosis at birth for 18 } & \text { - Serum and urinary } \\ \text { months and group B } & \text { levels of calcium, } \\ \text { after 6 months for 12 } & \text { phosphorus, } \\ \text { months. Group C } & \text { creatinine, serum } \\ \text { received no BP treatment } & \text { alkaline phosphatase, } \\ \text { in the first 2 years of life. } & \text { 25-hydroxyvitamin D, } \\ \begin{array}{l}\text { All families received } \\ \text { counseling from a }\end{array} & \text { insulin-like growth } \\ \text { nutritionist to ensure } & \text { factor-l, parathyroid } \\ \text { that all patients had a } & \text { hormone, } \\ \text { vitamin D intake of at } & \text { osteocalcium, urinary } \\ \text { least } 400 \text { IU/day and a } & \text { N-terminal telopeptide } \\ \text { calcium intake of at least } & \text { Radiological data: } \\ \text { of } 600 \text { mg/day } & \text { - Lateral radiography of } \\ & \text { the vertebral column }\end{array}$

- Fracture incidence: group A had a lower incidence of fractures (2.4 vs. 6.0 and 6.8 fractures/year; $\mathrm{p}<0.05)$ than groups $\mathrm{B}$ and $\mathrm{C}$ in the first 6 months of treatment. In the second 6 months, both groups $\mathrm{A}$ and $\mathrm{B}$ had a lower fracture rate than group C (2.0 and 2.8 vs. 5.4 fractures/year; $\mathrm{p}<0.05)$.

- Adverse events: only the well-known acute-phase reaction after the first infusion cycle was seen in 9 patients $(90 \%)$, with short-term fever up to $38.5^{\circ} \mathrm{C}$, responsive to acetaminophen. There was no urinary protein excretion, white blood cell count reduction, or respiratory distress syndrome.

- Bone pain: signs of bone pain, present in all children before treatment, tended to disappear in treated infants.

- uNTX: a significant decline over time of uNTX/uCr ratios was observed and $\mathrm{uNTx} / \mathrm{uCr}$ ratios were significantly lower after 12 (group A, $1,200 \pm 388 \mathrm{nmol} \mathrm{BCE} / \mathrm{mmol}$ ) and 6 months (group B, $1,380 \pm 355 \mathrm{nmol}$ $\mathrm{BCE} / \mathrm{mmol}$ ) of intravenous neridronate therapy compared to untreated patients (group C, 1,870 $\pm 430 \mathrm{nmol} \mathrm{BCE} / \mathrm{mmol}$; group $\mathrm{A}$ and $\mathrm{B}$ vs. group $\mathrm{C} ; \mathrm{p}<0.050)$.

Projection area: an increase in radiographically determined vertebral projected area was reported in all treated patients. After 6 months the change in projected area in treatment group A was significantly greater compared to group B (no treatment in the first 6 months) and control group C ( $4.0 \pm 0.8,3.2 \pm 0.7$, and $3.1 \pm 0.8 \mathrm{~cm}^{2}$, respectively; both $\mathrm{p}<$ $0.050)$. After $12\left(5.1 \pm 1.0,4.5 \pm 0.9 \mathrm{~cm}^{2}\right.$, and $3.8 \pm 0.9 \mathrm{~cm}^{2}$, respectively) and 18 months $\left(5.8 \pm 1.1,5.2 \pm 1.2 \mathrm{~cm}^{2}\right.$, and $4.3 \pm 1.0 \mathrm{~cm}^{2}$, respectively), the differences between group $A$ and $C$ were still significant $(\mathrm{p}<0.050)$. 
Table 1 (continued)

\begin{tabular}{|c|c|c|c|c|c|}
\hline $\begin{array}{l}\text { First author } \\
\text { [Ref.], location }\end{array}$ & $\begin{array}{l}\text { Study } \\
\text { design }\end{array}$ & $\begin{array}{l}\text { Patients/controls } \\
\text { OI type(s); } \\
\text { age at baseline }^{\mathrm{b}}\end{array}$ & Treatment/intervention & Outcome measures & Results \\
\hline $\begin{array}{l}\text { Bishop [32] } \\
\text { (multicenter), } \\
\text { Sheffield } \\
\text { Children's } \\
\text { Hospital } \\
\text { (Sheffield, UK) }\end{array}$ & RCT & $\begin{array}{l}147 \text { (I: } \mathrm{n}=97 \\
\text { P: } \mathrm{n}=50) \\
\text { multiple types; } \\
\text { I: } 8.9 \pm 3.4 \\
\text { P: } 8.6 \pm 3.1 \text { years }\end{array}$ & $\begin{array}{l}\text { I: oral risedronate at } \\
2.5 \mathrm{mg} / \text { day in children } \\
\text { weighing } 10-30 \mathrm{~kg} \text { and } \\
5 \mathrm{mg} / \text { day in children } \\
>30 \mathrm{~kg} \\
\mathrm{P} \text { : placebo tablets } \\
\text { After } 1 \text { year, all children } \\
\text { received risedronate for } \\
2 \text { additional years in an } \\
\text { open-label extension, } \\
\text { dosed in accordance } \\
\text { with their weight at the } \\
\text { end of year } 1 \\
\text { All patients received } \\
\text { daily calcium (500- } \\
1,000 \mathrm{mg} \text { ) and vitamin D } \\
\text { (200-600 IU) } \\
\text { appropriate for their } \\
\text { weight }\end{array}$ & $\begin{array}{l}\text { Primary: } \\
\text { - Percentage change } \\
\text { from baseline in } \\
\text { lumbar spine aBMD at } \\
\text { the } 1 \text { year endpoint } \\
\text { Secondary: } \\
\text { - Percentage change } \\
\text { from baseline in total } \\
\text { body aBMD } \\
\text { - Change in z-score for } \\
\text { the lumbar spine and } \\
\text { total body areal BMD } \\
\text { - Incidence and rate of } \\
\text { new vertebral collapses } \\
\text { - Incidence and rate of } \\
\text { clinical vertebral and } \\
\text { nonvertebral fractures } \\
\text { - Percentage change } \\
\text { from baseline in bone } \\
\text { turnover markers } \\
\text { - Safety (adverse events, } \\
\text { laboratory data, vital } \\
\text { signs, findings of } \\
\text { physical examinations) }\end{array}$ & 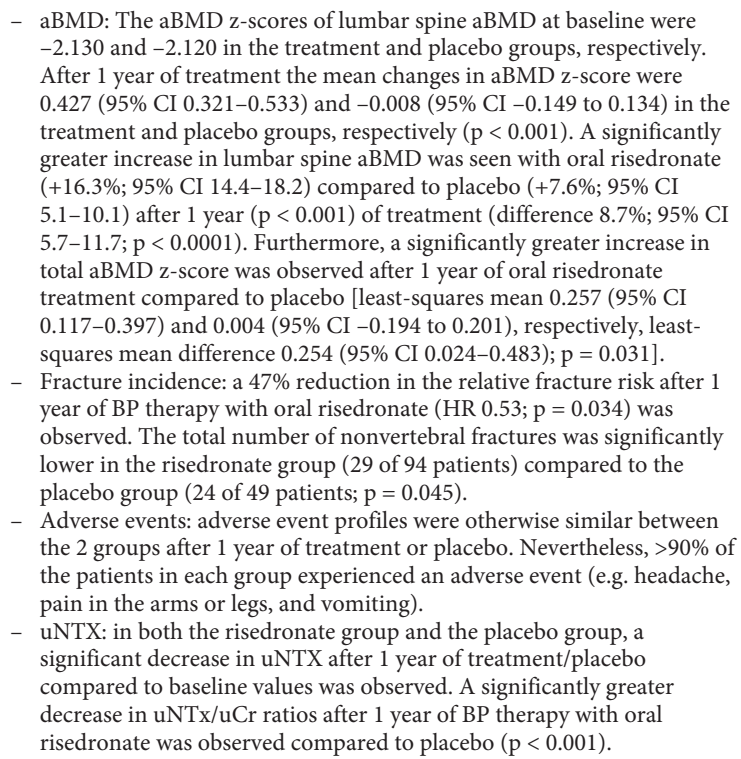 \\
\hline
\end{tabular}

OS = Observational study; $\mathrm{I}=$ intervention; $\mathrm{P}=$ placebo $\mathrm{C}=$ control; SGPT = serum glutamic-pyruvic transaminase; $\mathrm{PTH}=$ parathyroid hormone; CTX = carboxy-telopeptide cross-links of type $\mathrm{l}$ collagen; ALP $=$ alkaline phosphatase; $\mathrm{BMD}=$ bone mineral density; NA $=$ not applicable. ${ }^{\mathrm{a}}$ Presented as numbers. ${ }^{\mathrm{b}}$ Presented in years as means $\pm \mathrm{SD}$.

Table 2. Methodological quality (risk of bias)

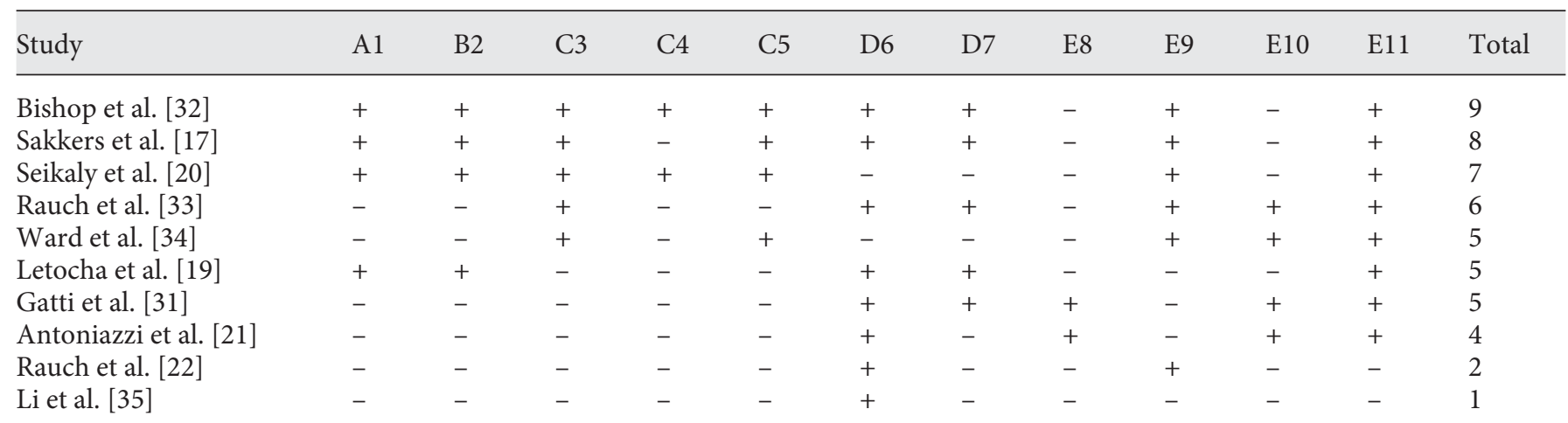

$\mathrm{A} 1=$ Adequate method of randomization; $\mathrm{B} 2=$ concealed allocation of treatment; $\mathrm{C} 3=$ patient was blinded; $\mathrm{C} 4=$ care provider was blinded; C5 = outcome assessor was blinded; D6 = drop-out was described and acceptable; D7 = participants were analyzed in allocated groups; E8 = groups were similar at baseline; E9 = cointerventions were avoided or similar; E10 = compliance was acceptable in all groups; E11 = timing of outcome assessment was similar in all groups.

\section{Methodological Quality (Risk of Bias)}

The Cochrane scores for risk of bias are listed in table 2. Interrater agreement was good $(\kappa=0.75)$. Four studies ( $40 \%$ ) scored $\geq 6$ out of 11 points and were identified as having a low risk of bias [17, 20,32,33], whereas the other 6 studies were identified as having a high risk of bias $[19,21,22,31,34,35]$. The included studies regarding intravenous pamidronate $[19,22]$, intravenous neridronate [21,31], oral alendronate [34], and intravenous ibandronate [35] showed the lowest methodological quality (scores $\leq 5$ point on the Cochrane scores for risk of bias). 


\section{Areal Bone Mineral Density}

Nine studies [17, 19, 20, 22, 31-35] measured aBMD, and 8 of these $[17,19,20,31-35]$ indicated a significant increase in bone mineral density compared to placebo as a result of BP treatment. One study [22] also found a significant change; however, it evaluated the effects of discontinuation of BP treatment (see Pamidronate). The included studies assessed aBMD as lumbar spine aBMD, hip aBMD, and/or total body aBMD.

\section{Lumbar Spine aBMD}

Risedronate: The studies of both Bishop et al. [32] and Rauch et al. [33] showed a significantly greater increase in lumbar spine aBMD with oral risedronate $(+16.3$ and $+23.8 \pm 15.4 \%$, respectively; $95 \%$ CI 14.4-18.2) compared to placebo $(+7.6$ and $+6.8 \pm 10.6 \%$, respectively; $95 \%$ CI $5.1-10.1)$ after 1 year of treatment $(\mathrm{p}<0.001)$ in the study of Bishop et al. [32] and after 2 years of treatment ( $p=$ 0.003) in the study of Rauch et al. [33]. In the study of Bishop et al. [32], the aBMD z-scores of lumbar spine aBMD at baseline were -2.130 and -2.120 in the treatment and placebo groups, respectively. After 1 year of treatment, the mean changes in aBMD z-score were 0.427 (95\% CI 0.321-0.533) and -0.008 (95\% CI -0.149-0.134) in the treatment and placebo groups, respectively $(\mathrm{p}<$ 0.001). In the study of Rauch et al. [33], the z-scores of lumbar spine aBMD at baseline were $-2.97 \pm 0.97$ and $-2.66 \pm 0.86$ in the treatment and placebo groups, respectively. After 2 years of treatment, the z-scores of lumbar spine aBMD increased significantly, more with risedronate $(+0.65 \pm 0.65)$ compared to placebo $(-0.15 \pm 0.39)$ $(\mathrm{p}=0.002)$.

Alendronate: A significant increase $(\mathrm{p}<0.001)$ in lumbar spine aBMD with oral alendronate treatment (mean change in $z$-score of $+0.89 \pm 0.19$ and +1.32 , respectively; 95\% CI 1.08-1.56) compared to placebo (mean change in $z$-score of $-0.12 \pm 0.14$ and +0.14 , respectively; $95 \%$ CI $-0.21-0.48$ ) was reported by Seikaly et al. [20] after 1 year of treatment and by Ward et al. [34] after 2 years of treatment. In the latter study, the $\mathrm{z}$-scores changed after 2 years of treatment from -4.6 to -3.3 in the alendronate group and from -4.6 to -4.5 in the placebo group [34]. The change in the alendronate group was significant $(\mathrm{p}<$ 0.001 ), whereas the change in the placebo group was not significant.

Olpadronate: Sakkers et al. [17] measured a significantly greater increase in lumbar spine aBMD with oral olpadronate compared to placebo. At baseline, the lumbar spine aBMD was $0.31 \pm 0.16 \mathrm{~g} / \mathrm{cm}^{2}$ in the olpadronate group and $0.32 \pm 0.14 \mathrm{~g} / \mathrm{cm}^{2}$ in the placebo group. After
2 years of treatment, the adjusted annual difference in lumbar spine aBMD was $0.054 \mathrm{~g} / \mathrm{cm}^{2}$ (95\% CI 0.012 $0.096 ; p=0.010$ ). Spinal $z$-scores increased from -4.98 to -3.31 in the olpadronate group and from -4.84 to -4.70 in the placebo group after 2 years of treatment. The adjusted group difference in lumbar spine aBMD was 0.74 (95\% CI 0.29-1.19; $\mathrm{p}=0.002$ ).

Neridronate: Gatti et al. [31] measured a significantly greater increase in lumbar spine aBMD with intravenous neridronate $(+18 \%)$ than with placebo $(+3.5 \%)$ after 1 year of treatment $(\mathrm{p}<0.001)$. In the control group, which also received neridronate after 1 year, spine z-scores did not change during the subsequent year of treatment, whereas in the neridronate group z-scores increased significantly (from -3.39 to -2.01 ) over 3 years $(p<0.001$ ). Furthermore, in both groups treatment was associated with spine bone mineral density changes of 30,20 , and $15 \%$ during the first, second, and third year, respectively.

Pamidronate: Two studies $[19,22]$ evaluated the effects of treatment with pamidronate on lumbar aBMD. Letocha et al. [19] noted that lumbar spine aBMD z-scores increased significantly more $(\mathrm{p}<0.001)$ with intravenous pamidronate (from $-5.44 \pm 1.46$ to $-4.04 \pm 1.48$; $p<0.001$ ) than with placebo (from $-5.74 \pm 0.78$ to $-5.77 \pm 0.90 ; \mathrm{p}=$ 0.880 ) after 1 year of treatment. However, z-scores did not further increase during the second year of treatment in the pamidronate group ( $\mathrm{p}<0.001)$. Furthermore, a study by Rauch et al. [22] found that the change in lumbar spine aBMD (in $\mathrm{g} / \mathrm{cm}^{2}$ ) after 2 years in the group that continued intravenous pamidronate treatment was not different from the change in lumbar spine aBMD (in g/ $\mathrm{cm}^{2}$ ) in the group that discontinued treatment (mean change $+0.05 \pm 0.07$ and $+0.01 \pm 0.03 \mathrm{~g} / \mathrm{cm}^{2}$, respectively; $\mathrm{p}=0.070$ ). However, the change in lumbar spine aBMD $\mathrm{z}$-score was significantly different between the groups (mean change $+0.2 \pm 0.7$ and $-0.4 \pm 0.4$ in the group that continued therapy and the group that discontinued therapy, respectively; $\mathrm{p}=0.010$ ).

Ibandronate: Only the study of Li et al. [35] evaluated the effect of ibandronate on lumbar spine aBMD. The results indicated significant increases of $59.0 \%$ in the intravenous ibandronate group $(\mathrm{p}<0.010)$ and $24.6 \%$ in the control group $(\mathrm{p}<0.050)$ after 2 years of treatment. The change in lumbar spine aBMD during the intervention period was significantly lower in the control group compared to the intervention group $(\mathrm{p}<0.050)$.

\section{Hip aBMD}

Aside from lumbar spine aBMD, 3 studies [31, 33, 35] also measured hip aBMD, and 2 of these studies $[31,35]$ DOI: $10.1159 / 000381713$
Rijks/Bongers/Vlemmix/Boot/van Dijk/ Sakkers/van Brussel 
indicated a significant increase in hip aBMD as a result of neridronate and ibandronate treatment.

Neridronate: Gatti et al. [31] measured a significantly greater increase in hip aBMD in the intravenous neridronate group than in the placebo group after 1 year of treatment $(+25$ and $+5.7 \%$, respectively; $p<0.001)$. In the second and third study years, the control group was also treated with neridronate. In both groups this active treatment caused changes in hip aBMD of $15 \%$ during the second year of treatment and $8 \%$ throughout the third year of treatment.

Ibandronate: In the study of Li et al. [35], hip aBMD significantly increased by $36.6 \%$ after 2 years of treatment with intravenous ibandronate $(\mathrm{p}<0.001)$ and by $26.9 \%$ with calcitriol $(\mathrm{p}<0.050)$. Hip aBMD increased significantly more with ibandronate during the 2 -year treatment period $(\mathrm{p}<0.050)$.

Risedronate: The study of Rauch et al. [33] indicated no significant change in hip aBMD after 2 years of treatment with oral risedronate compared to placebo (mean change $12.4 \pm 10.8$ and $6.5 \pm 5.9 \%$, respectively; $\mathrm{p}=0.110$ ).

\section{Total Body aBMD}

Risedronate: The studies of Bishop et al. [32] and Rauch et al. [33] also measured total body aBMD. Bishop et al. [32] demonstrated a significantly greater increase in total aBMD z-score after 1 year of oral risedronate treatment compared to placebo [least-squares mean 0.257 (95\% CI 0.117-0.397) and 0.004 (-0.194 to 0.201), respectively, and least-squares mean difference 0.254 (95\% CI $0.024-0.483) ; p=0.031]$. However, the study of Rauch et al. [33] did not find a significantly greater increase in total body aBMD with oral risedronate compared to placebo after 2 years of treatment (change $10.7 \pm 7.1$ and $6.5 \pm$ $4.6 \%$, respectively; $\mathrm{p}=0.090$ ).

\section{Fracture Incidence}

All included studies [17, 19-22, 31-35] assessed the effects of BPs on fracture incidence, and 6 of these studies $[17,19,21,31,32,35]$ indicated a significant reduction in relative fracture risk or annual fracture rate as a result of BP therapy. One study [20] reported a significant reduction in fracture incidence; however, it did not indicate a hazard ratio (HR) or $\mathrm{p}$ value. Three studies $[22,33,34]$ reported a nonsignificant relative risk of fractures or a difference in the number of fractures. Only one study measuring vertebral fractures separately from nonvertebral fractures revealed differentiation between the two types of fractures [32]. That study reported a nonoccurrence of vertebral fractures in the risedronate group and the pla- cebo group [32]. Regarding nonvertebral fractures, most of the included studies reported only long-bone fractures $[17,19,21,22,33,34]$, except for 3 studies $[31,32,35]$ which also reported fractures in the ribs, scapula, and clavicle. One study [20] reported no specification of the type of fractures measured.

\section{Significant Reduction}

Risedronate: Bishop et al. [32] reported a 47\% reduction in relative fracture risk after 1 year of $\mathrm{BP}$ therapy with oral risedronate (HR 0.53; $\mathrm{p}=0.034$ ). The total number of nonvertebral fractures was significantly lower in the risedronate group ( 29 in 94 patients) compared to the placebo group (24 in 49 patients) ( $\mathrm{p}=0.045)$. The total number of nonvertebral long-bone fractures was 18 in the risedronate group $(\mathrm{n}=94)$ and 17 in the placebo group $(\mathrm{n}=$ 49 , no $\mathrm{p}$ value reported)

Olpadronate: Sakkers et al. [17] reported a significant reduction of $31 \%$ in relative fracture risk after 2 years of treatment with oral olpadronate (HR $0.69 ; p=0.010)$. The total number of fractures was 18 in 16 patients in the olpadronate group and 50 in 18 patients in the placebo group ( $\mathrm{p}$ value not mentioned).

Neridronate: Gatti et al. [31] reported a significantly lower total number of fractures in the intravenous neridronate group (13 in 42 patients) compared to the placebo group (18 in 22 patients). The corresponding relative risk was $0.36(\mathrm{p}<0.050)$. Antoniazzi et al. [21] performed a study in infants with OI in which group A started treatment just after diagnosis at birth for 18 months, group B started treatment after 6 months for 12 months, and group $\mathrm{C}$ was the control group. They noted a significantly lower annual fracture rate in group A compared to groups $\mathrm{B}$ and $\mathrm{C}$ during the first 6 months of intravenous neridronate (2.4 vs. 6.0 and 6.8 fractures/year; $\mathrm{p}<0.050)$. During the second 6 months, both intravenous neridronate groups (A and $\mathrm{B}$ ) had a significantly lower annual fracture rate compared to the control group C (2.0 and 2.8 vs. 5.4 fractures/year; $\mathrm{p}<0.05$ ).

Pamidronate: Letocha et al. [19] showed a significantly decreased fracture rate in the upper extremities $(\mathrm{p}=$ $0.040)$ but not in the lower extremities $(\mathrm{p}=0.090)$ after 1 year of intravenous pamidronate treatment. After 2 years of treatment, the fracture rate did not decrease further in the upper extremities $(\mathrm{p}=0.840)$ or the lower extremities $(\mathrm{p}=0.290)$.

Ibandronate: In the study of Li et al. [35], the annual new fracture rate was significantly reduced (from 1.9 to $0.13 ; \mathrm{p}<0.001)$ in the intravenous ibandronate group after 2 years of BP therapy and it was significantly lower 
than in the control (calcitriol) group ( $\mathrm{p}<0.001)$, which indicated a slight tendency towards a decrease (from 1.8 to $1.0 ; \mathrm{p}>0.050)$.

\section{Implied Significant Reduction (No p Value or HR} Mentioned)

Alendronate: Seikaly et al. [20] reported 3 fractures in the oral alendronate group $(\mathrm{n}=10)$ and 9 fractures in the placebo group $(\mathrm{n}=10)$ during 1 year of $\mathrm{BP}$ treatment.

\section{Nonsignificant Differences}

Risedronate: Rauch et al. [33] did not find any significant differences in the number of fractures during 2 years of BP therapy with risedronate. Seven patients in the risedronate group and 6 patients in the placebo group sustained at least 1 fracture; a total of 11 fractures occurred in both groups during the study interval.

Pamidronate: Rauch et al. [22] reported 13 fractures in the group that discontinued intravenous pamidronate $(\mathrm{n}=12)$ and 6 in the group that continued pamidronate treatment $(\mathrm{n}=12)$ for 2 years $(\mathrm{p}=0.480)$.

Alendronate: Ward et al. [34] reported a relative risk of having $\geq 1$ new long-bone fracture of 1.04 (95\% CI 0.81$1.34)$ in the oral alendronate group. The number of patients with $\geq 1$ long-bone fracture was $71(75 \%)$ in the alendronate group $(\mathrm{n}=95)$ and $21(72 \%)$ in the placebo group $(n=29)$.

\section{Adverse Events}

All included studies [17, 19-22, 31-35] described adverse events as an outcome measure, and 9 of these studies [19-22, 31-35] reported actual adverse events and 1 study [17] reported no adverse events after BP treatment.

Risedronate: Bishop et al. [32] reported no differences in adverse events after 1 year of treatment with oral risedronate compared to placebo. Nevertheless, $>90 \%$ of the patients in each group experienced an adverse event (e.g. headaches, pain in the arms or legs, and vomiting). Rauch et al. [33] reported that all patients had at least 1 adverse event after 2 years of BP therapy with oral risedronate. The number of patients with gastrointestinal complaints did not differ statistically between groups $(\mathrm{p}=0.420)$.

Alendronate: Seikaly et al. [20] reported that 2 children (12\%) had abdominal discomfort after oral alendronate, which was immediately relieved after instructions for administration were followed. Ward et al. [34] noted that gastrointestinal complaints were the most reported adverse events, but the occurrence was not significantly different between the oral alendronate and placebo groups $(\mathrm{p}=0.836)$. Only abdominal pain and vomiting were attributed to alendronate.

Neridronate: Gatti et al. [31] noted that 10 patients (24\%) had an acute-phase reaction (flu-like symptoms) after the first intravenous neridronate infusion. After the second infusion an attenuated response was noted by all of them. Antoniazzi et al. [21] also noted an acute-phase reaction with short-term fever in 9 patients (90\%) after the first intravenous neridronate infusion cycle.

Pamidronate: Letocha et al. [19] reported that all patients experienced acute-phase reactions after the first intravenous pamidronate infusion. Rauch et al. [22] noted that 2 patients who stopped intravenous pamidronate treatment began to feel unwell and lacked stamina, and therefore treatment was resumed 15 and 16 months after cessation. Two weeks later these symptoms disappeared.

Ibandronate: Li et al. [35] did not report any serious adverse events in either the treatment or the control (calcitriol) group. However, in $65 \%$ of the patients fever with muscle soreness occurred after the first intravenous ibandronate infusion. After subsequent infusions these symptoms did not recur.

Olpadronate: In contrast to all of the above-mentioned studies, one study [17] did not report any acute-phase reactions or adverse events after oral olpadronate use.

\section{(Bone) Pain}

Five studies [19-21, 33, 34] measured (bone) pain, and 2 of these studies [20,34] indicated significant improvement in scores of pain as a result of BP treatment.

Alendronate: Ward et al. [34] found significantly fewer patients with bone pain in the oral alendronate group at 24 months compared to baseline $(\mathrm{p}<0.001)$; however, compared to controls, the difference in the percentage of patients with bone pain at 24 months was not significant $(p=0.065)$. Furthermore, no significant difference was observed in the number of days per week during which patients suffered from bone pain $(p=0.167)$. Seikaly et al. [20] showed a significant decrease $(\mathrm{p}<0.001)$ in pain score (in days/week) after oral alendronate treatment (mean change $-3.13 \pm 0.63$ ) compared to placebo (mean change $0.50 \pm 0.47$ ) after 1 year of treatment.

Neridronate: Antoniazzi et al. [21] merely described that signs of bone pain tended to disappear in the intravenous neridronate groups; however, no comparisons were made with the control groups.

\section{Nonsignificant Differences}

Two studies $[19,33]$ indicated no significant change in (bone) pain as a result of oral risedronate [33] or intrave-
36

Horm Res Paediatr 2015;84:26-42 DOI: $10.1159 / 000381713$
Rijks/Bongers/Vlemmix/Boot/van Dijk/ Sakkers/van Brussel 
nous pamidronate [19] treatment, respectively. In the study of Letocha et al. [19], pain scores changed from 3.75 \pm 0.71 to $3.44 \pm 0.82(\mathrm{p}=0.300)$ and from $3.94 \pm 0.18$ to $3.55 \pm 0.73(p=0.170)$, respectively, in the pamidronate and control groups after 1 year of treatment. In the study of Rauch et al. [33], 2 patients in the risedronate group and 8 patients in the control group experienced bone pain at baseline, and after 2 years of treatment 4 patients in each group suffered from bone pain.

\section{Urinary Markers of Bone Resorption}

Seven of the included studies [17, 20-22, 32-34] measured urinary markers of bone resorption, and 5 of these studies $[20-22,32,34]$ reported a significant decrease in levels of the bone resorption marker urinary cross-linked $\mathrm{N}$-telopeptide of type I collagen (uNTx) or in uNTx divided by urinary creatinine $(\mathrm{uNTx} / \mathrm{uCr})$ after BP treatment. Furthermore, 4 of these 5 studies [20, 21, 32, 34] found a significant decrease in $\mathrm{uNTx} / \mathrm{uCr}$ compared to the control group.

\section{Significant Decreases}

Risedronate: Bishop et al. [32] reported a significantly larger decrease in $\mathrm{uNT} / \mathrm{uCr}$ ratios after 1 year of $\mathrm{BP}$ therapy with oral risedronate compared to placebo $(\mathrm{p}<0.001)$.

Alendronate: Ward et al. [34] reported that uNTx levels decreased significantly $(\mathrm{p}<0.001)$ more in the oral alendronate group than in the control group after 24 months [mean change $-62.2 \%$ (95\% CI -67.4 to -56.1 ) and $-32.0 \%$ (95\% CI -46.7 to -13.3 ), respectively]. In the alendronate group, uNTX decreased from 131 to $63 \%$ of the healthy average, and in the control group uNTX decreased from 128 to $112 \%$ (95\% CI for the difference in change -87 to $-15 ; \mathrm{p}=0.006)$. Seikaly et al. [20] reported a significant $(\mathrm{p}<0.010)$ decrease in $\mathrm{uNTx} / \mathrm{uCr}$ ratios of $56 \%$ in the treatment group after 1 year of oral alendronate (541 \pm 64 to $244 \pm 60 \mathrm{pmol} / \mu \mathrm{mol} \mathrm{Cr}$ ). The control group showed no significant effects on $\mathrm{uNTx} / \mathrm{uCr}$ ratios after 12 months of placebo.

Neridronate: Antoniazzi et al. [21] reported a significant decline over time in uNTX/uCr ratios, and uNTx/ $\mathrm{uCr}$ ratios were significantly lower after 12 [group A, $1,200 \pm 388 \mathrm{nmol}$ bone collagen equivalents (BCE)/ mmol] and 6 months (group B, 1,380 $\pm 355 \mathrm{nmol} \mathrm{BCE/}$ $\mathrm{mmol}$ ) of intravenous neridronate therapy compared to untreated patients (group C, $1870 \pm 340 \mathrm{nmol} \mathrm{BCE} /$ mmol; group A and B vs. group $C$; $p<0.050$ ).

Pamidronate: Rauch et al. [22] reported that uNTx/ $\mathrm{uCr}$ ratios changed significantly after discontinuation or continuation of pamidronate therapy for 2 years, both in absolute value $(\mathrm{nmol} / \mathrm{mmol})$ and in the percentage of age and sex-specific reference means; $p=0.020$ and $p=0.008$, respectively. Two years after discontinuation of intravenous pamidronate, $\mathrm{uNTx} / \mathrm{uCr}$ ratios increased $(+36 \pm 87$ $\mathrm{nmol} / \mathrm{mmol},+22 \pm 28 \%$ ), and 2 years after continuation of intravenous pamidronate, $\mathrm{uNTX} / \mathrm{uCr}$ ratios decreased $(-0.54 \pm 86 \mathrm{nmol} / \mathrm{mmol},-12 \pm 30 \%)$.

\section{Nonsignificant Differences}

Risedronate: Rauch et al. [33] reported no significant difference in $\mathrm{uNTx} / \mathrm{uCr}$ ratios (change $-27.7 \pm 33.6$ and $-10.7 \pm 43.7 \%$, respectively; $p=0.280$ ) after 2 years of oral risedronate compared to placebo, but in serum NTx a significant decrease was reported (change $-34.6+22.2$ and $-6.2+39.0 \%$, respectively; $\mathrm{p}=0.030$ ).

Olpadronate: Sakkers et al. [17] found no significant differences within or between groups in urinary C-telopeptides/creatinine and D-deoxypyridinolines/creatinine [difference -114.5 (95\% CI -281.2 to 52.3$)$ and -1.98 (95\% CI -6.56 to 2.60 ); $\mathrm{p}=0.190$ and $\mathrm{p}=0.400$, respectively] after 2 years of oral olpadronate or placebo.

\section{Projection Area}

Six studies $[19,21,22,31,33,34]$ measured the lumbar spine projection area, and 3 of these studies $[19,21,31]$ indicated a significant increase as a result of intravenous BP treatment. The projection area of L1-L4 was determined by dual-energy X-ray absorptiometry (DXA), unless otherwise stated.

\section{Significant Increase}

Neridronate: Gatti et al. [31] showed a significantly higher $(\mathrm{p}<0.050)$ mean percent increase in the projected area of the lumbar spine in the intravenous neridronate group after 1 year $(6.68 \pm 8.1 \%$; $p<0.010$ vs. baseline $)$ compared to the control group $(1.97 \pm 3.3 \%$; $p<0.05$ vs. baseline). Antoniazzi et al. [21] reported an increase in the radiographically determined vertebral projected area in all treated patients. After 6 months the change in projected area in treatment group A was significantly greater compared to group B (no treatment in the first 6 months) and the control group $C(4.0 \pm 0.8,3.2 \pm 0.7$, and $3.1 \pm 0.8$ $\mathrm{cm}^{2}$, respectively; both $\left.\mathrm{p}<0.050\right)$. After $12(5.1 \pm 1.0,4.5$ \pm 0.9 , and $3.8 \pm 0.9 \mathrm{~cm}^{2}$, respectively) and 18 months (5.8 $\pm 1.1,5.2 \pm 1.2$, and $4.3 \pm 1.0 \mathrm{~cm}^{2}$, respectively), the differences between groups $\mathrm{A}$ and $\mathrm{C}$ were still significant $(\mathrm{p}<0.050)$.

Pamidronate: Letocha et al. [19] showed a significant change in the radiologically defined summed L1-L4 vertebral area after 1 year of pamidronate $(1.35 \pm 0.95$ to 1.74 
$\pm 0.99 \mathrm{~cm}^{2} ; \mathrm{p}=0.006$ ). After the second year (extended treatment period, 6-21 months), the vertebral area still increased, but this increase was not significant (1.76 \pm $0.59 \mathrm{~cm}^{2} ; \mathrm{p}=0.110$ ). Compared to placebo, the summed L1-L4 vertebral area increased significantly more after 1 year of pamidronate $(\mathrm{p}=0.005)$. Because vertebrae T12, L1, and L2 were most likely to experience compressions from weight bearing, these were also examined. The L2 vertebral area increased significantly more in the treatment group compared to placebo $(\mathrm{p}=0.020)$. In the second year of treatment (extended treatment period), the $\mathrm{L} 2$ vertebral area did not increase further $(\mathrm{p}=0.340)$. The T12-L2 vertebral area of the pamidronate group also increased significantly more after 1 year of pamidronate compared to placebo $(\mathrm{p}=0.050)$, but during the extended treatment period the T12-L2 vertebral area did not increase significantly $(\mathrm{p}=0.250)$. The vertebral area of $\mathrm{T} 12$ and L1 showed no significant difference in the rate of increase between groups during the first year $(p=0.130$ and $\mathrm{p}=0.710$, respectively).

\section{Nonsignificant Differences}

Three studies $[22,33,34]$ did not measure a significant increase in lumbar spine projection area after BP treatment compared to a placebo group, a matched OI type I, III, and IV group, or a group that discontinued pamidronate treatment.

Pamidronate: Rauch et al. [22] did not measure a significantly different increase in lumbar spine area between the group that discontinued pamidronate treatment and a group that continued it after 2 years (mean change \pm SD: $2.2 \pm 2.9$ and $2.9 \pm 5.8 \mathrm{~cm}^{2}$, respectively; $\mathrm{p}=0.720$ ).

Alendronate: Ward et al. [34] did not find a significantly different increase in lumbar spine area in the oral alendronate group compared to placebo after 2 years [mean change $14.2 \%$ (95\% CI 10.4-18.0) and $12.2 \%$ (95\% CI 6.7-17.6), respectively; $\mathrm{p}=0.493$ ].

Risedronate: Rauch et al. [33] did not measure a significantly different increase in lumbar spine area in the oral risedronate group compared to placebo after 2 years (mean change \pm SD: $16.4 \pm 13.8$ and $10.2 \pm 11.6 \%$, respectively; $\mathrm{p}=0.230$ ).

\section{Discussion}

The results of the current review show that children with OI benefit from BP treatment in several clinical, biochemical, and radiological outcomes. Moreover, (shortterm) therapy seems to be safe and well tolerated. All studies assessing lumbar spine aBMD independently showed significantly greater increases in lumbar spine aBMD ( $\left.\mathrm{z}^{-}\right)$scores in the BP treatment group (either oral or intravenous) compared to placebo or no treatment. These results are in line with findings from uncontrolled or retrospective studies [36-38]. Furthermore, most studies displayed the largest increase in aBMD during the first year of treatment $[19,22,31,33,35]$. During prolonged treatment the sustained increase in aBMD is less than during the first year of treatment. Two out of 3 studies assessing hip aBMD showed a significant increase after intravenous BP treatment [31,35]. The third study [33] showed an increase, though not significant, in hip aBMD after oral BP treatment. Merely 2 studies [32, 33] assessed total body aBMD after oral risedronate treatment and both showed an increase in total body aBMD. However, only 1 study reported a statistically significant increase [32]. The difference in sample size between these 2 studies $(\mathrm{n}=147$ vs. $\mathrm{n}=26)$ might explain these different statistical findings.

Most studies (70\%) indicated a significant $[17,19,21$, $31,32,35]$ or an implied significant [20] reduced fracture incidence after intravenous or oral BP treatment. None of the trials reported increased fractures with BP treatment. These results are generally in line with the review of Dwan et al. [39], although they included adult studies and noncontrolled studies as well. Though promising, the reduction in fracture incidence as a result of BP treatment is still not fully understood [40]. Several starting points/hypotheses can be formulated. BPs can increase the number (not the thickness) of trabeculae and the thickness of cortical bone, and BPs can improve long-bone geometry [41]. An increase in bone mineral density is related to a decrease in fracture risk, as each single SD reduction in total body aBMD approximately doubles the risk of new fractures at any site [42]. Furthermore, Clark et al. reported that the fracture risk in childhood was related to the estimated volumetric bone mineral density of the humerus and the size-adjusted total body bone mineral content [43]. On the other hand, in healthy children, total body aBMD largely reflects cortical bone and therefore it can be assumed that the relationship between a reduction in the fracture risk and total body aBMD is an increase in the external diameter of long bones. In contrast to healthy children, long bones in children with OI are typically narrow and, in addition, BPs reduce endosteal resorption but do not increase periosteal growth, emphasizing that an increase in total body aBMD in children with OI will not inevitably decrease the fracture risk. Two $[33,34]$ of the 3 studies $[22,33,34]$ that did not show a significant reduc-
38

Horm Res Paediatr 2015;84:26-42 DOI: $10.1159 / 000381713$
Rijks/Bongers/Vlemmix/Boot/van Dijk/ Sakkers/van Brussel 
tion in fracture incidence administered BPs orally. However, no consensus could be reached regarding the preferred administration method as the 3 studies with the highest methodological quality using oral BP treatment $[17,20,33]$ did show significant reductions. Although most studies indicate a significant decrease in fracture incidence after BP treatment, several confounding factors (such as natural changes in fracture incidence with age, adaptations of hormonal blood levels, and changes in physical activity behavior) should be taken into account during childhood. In addition, fracture incidence was reported in several ways. It would have been useful if absolute numbers of fractures per patient, as well as the number of patients that suffered a fracture and perhaps even the time to fracture, had been reported in every study, facilitating comparison of the results in the future. Moreover, assessment of and clear differentiation between vertebral and fractures of extremities should be made in future studies.

Only a few, mostly mild and reversible, short-term adverse effects have been reported as a direct result of $\mathrm{BP}$ treatment. These findings are like those in the review of Castillo et al. [1], though differences in adverse effects can be distinguished between oral and intravenous BP treatment. All studies using intravenous treatment reported the predominant occurrence of acute reactions (flu-like symptoms) only after the first infusion cycle $[19,21,31$, 35]; however, no adverse events recurred during subsequent infusions [31,35]. Acute-phase reactions may be due to upstream accumulation of isopentyl pyrophosphate acting on $\gamma \delta$-T cells to initiate cytokine release [44]. The latter can be controlled with simple analgesics. Although earlier studies have also indicated hypocalcemia as a side effect [23-28], the studies in the current review mentioning hypocalcemia depicted no symptoms related to hypocalcemia and no low serum calcium levels were found $[20,31]$. In these studies, hypocalcemia was likely prevented by supplementary administration of vitamin D and/or calcium [20,31], indicating its clinical value. In studies using oral BP treatment, most patients reported predominantly gastrointestinal or abdominal complaints, headache, vomiting, and pain in the arms or legs as adverse events [32-34]. However, the number of patients with an adverse event did not differ between the BP and control groups. Furthermore, one study [17] showed no adverse events at all after oral BP treatment.

More than half $(60 \%)$ of the included studies assessing (bone) pain $[20,21,34]$ measured a decrease in pain as a result of oral or intravenous BPs. Similar results have also been seen in several uncontrolled trials reporting a reduc- tion in (bone) pain [45-48]. However, our results in children deviated from the review of Dwan et al. [39] in which a reduction in bone pain was found in merely 1 out of 6 studies; however, they included adult studies and studies comparing different doses of BP without control groups [39]. Two included studies in our review did not measure a significant reduction in (bone) pain; however, the patients in these studies already reported a low pain score at baseline $[19,33]$. The perception and level of pain are subjective and difficult to compare between patients and studies. Although pain is even more difficult to rate objectively in children, this outcome measure is of great clinical relevance as pain complaints are frequently indicated at the end of a treatment cycle or just before a new administration of BPs.

As expected, most studies regarding urinary markers of bone resorption observed a decrease in the $\mathrm{uNTx} / \mathrm{uCr}$ ratio during oral or intravenous BP treatment, as osteoclasts initiate bone resorption and BPs inhibit osteoclast activity [11]. However, 2 studies [17, 33] did not show a significant decrease in resorptive markers during oral treatment despite (significant) bone remodeling. In one study [17] not NTx but urine C-telopeptide and deoxypiridinoline were assessed. Furthermore, the low bioavailability of the administrated oral BPs $(0.65 \%$ for risedronate [49] and 3-4\% for olpadronate [50]) might explain in part these nonsignificant changes in resorptive markers. Although higher doses of oral BPs could lead to a stronger bone metabolism effect [33], wide variations between the different types of BPs regarding the biological activity on bone tissue should be taken into consideration in the interpretation of resorptive markers. Furthermore, resorptive markers merely indicate a change in bone homeostasis and are not reliable indicators of acute change [39].

There are contradictory findings regarding the lumbar projection area, as only half of the studies showed a significant increase in lumbar projection area $[19,21,31]$ as a result of (intravenous) BP treatment. However, this latter is in accordance with several retrospective and uncontrolled studies [25, 28, 38, 45]. Remarkably, studies administrating BPs orally did not report significant changes compared to controls, whereas studies administering BPs intravenously did. Bone area is related to bone size, which may be important for bone strength if adjusted for body size, as bone size depends on longitudinal growth. In the study of Gatti et al. [31], bone area as well as height increased more in the treatment group than in the control group. However, BP treatment was not conclusively shown to impact vertical growth [39]. Vertebral height 
and the concavity index are considered better indicators of vertebral fractures compared to the projection area. Although, the studies in the current review did not report on the concavity index, retrospective studies of Land et al. $[38,51]$ only found a significant increase in the treatment (intravenous pamidronate) groups. However, no significant differences were found between the treatment group (OI type VI) and the control group (including patients with type I, II, and IV) [51], and instead of a longitudinal comparison with the controls, a cross-sectional analysis was performed with historical matched patients (not receiving pamidronate treatment) [38].

All included studies showed comparable mean ages at baseline (ranging from 7.9 to 11.9 years), except for the study of Antoniazzi et al. [21], which described infants with a mean age of 33 days. Although the latter study included infants, similar effects of BP treatment were found compared to the other included studies. Furthermore, all studies included multiple types of OI (mainly I, III, and IV) in their cohorts, except for the studies of Rauch et al. [33] and Antoniazzi et al. [21], who described, respectively, type I and III as the single investigated type of OI. Strikingly, the study of Rauch et al. [33] did not find significant changes in fracture rates, bone pain, $\mathrm{uNTx} / \mathrm{uCr}$ ratios, or projection area. Both studies indicated the plausibility that distinct OI types might differently respond to BP therapy. Although clinically different types of OI should be separately investigated to observe the effects of BPs, it is unethical to conduct placebo-controlled studies in severe types of OI (e.g. type III), which respond well to current BP treatment as indicated by Antoniazzi et al. [21].

A few limitations of this review need to be mentioned. Sixty percent of the included studies had poor methodological quality, which generates several types of biases (table 2). Strikingly, all studies with a low risk of bias used oral BPs and all studies with a high risk of bias used intravenous BPs. Moreover, different follow-up periods make comparisons between studies difficult and, in addition to this, assessing bone health in children who are of different heights, have different growth rates, and are in different stages of puberty, is difficult too. In one study [31], textual data of aBMD seemed different compared to data depicted in figures. However, both revealed greater increases in favor of the treatment group. These factors might have biased the general conclusions in this review, albeit not significantly, and therefore the results should be interpreted with some caution.

The results of the current review show that most children with OI benefit from BP treatment and (short-term) treatment seems to be safe and well tolerated. However, when interpreting outcome measures in children, various confounding factors should be taken into account, such as the individual/natural course of bone development and fracture incidence with age and the individual and possible changing bioavailability and biological activity of BPs on bone tissue during childhood. Although the included studies indicate that treatment is beneficial over several years (with the most benefits occurring during the first year of treatment), the optimal duration of BP treatment is still unknown and cannot be concluded upon from this review. Cyclical intravenous pamidronate is one of the oldest and most widely used type of nitrogenous BP in children with moderate to severe OI; however, merely 2 studies regarding intravenous pamidronate $[19$, 22 ] met the inclusion criteria and also displayed the lowest methodological quality, next to intravenous neridronate $[21,31]$ and intravenous ibandronate [35]. Based on the current review it is not feasible to answer the question of whether oral or intravenous administration of BPs is more beneficial or preferred in children, although oral BP treatment is contraindicated in very young children due to the risk of reflux-induced esophageal damage. Therefore, future longitudinal research with adequately powered RCTs (placebo controlled) is needed. The latter should further address the safety and efficacy of all clinically applied nitrogenous BPs (also including zoledronate) in order to substantiate or revise the current findings. Furthermore, these studies should also differentiate between clinical subgroups and focus on the optimal duration, bioavailability, biological activity, type, and dose of BP treatment, as well as potential long-term adverse effects of BP treatment in children with OI.

\section{Appendix 1}

Search String for PubMed

('Osteogenesis Imperfecta' [All Fields] OR 'Osteogenesis Imperfecta' [MeSH Terms] OR 'Brittle Bone Disease' [All Fields] OR 'Lobstein Disease' [All Fields] OR 'Fragilitas Ossium' [All Fields]) AND ('diphosphonates' [MeSH Terms] OR ('diphosphonates' [MeSH Terms] OR 'diphosphonates' [All Fields]) OR 'alendronate' [MeSH Terms] OR 'Clodronic acid' [MeSH Terms] OR 'Etidronic acid' [MeSH Terms] OR ('diphosphonates' [MeSH Terms] OR 'diphosphonates' [All Fields] OR 'bisphosphonate' [All Fields]) OR ('etidronic acid' [MeSH Terms] OR ('etidronic' [All Fields] AND 'acid'[All Fields]) OR 'etidronic acid' [All Fields] OR 'etidronate' [All Fields]) OR 'Etidronic acid' [All Fields] OR ('clodronic acid' [MeSH Terms] OR ('clodronic' [All Fields] AND 'acid' [All Fields]) OR 'clodronic acid' [All Fields] OR 'clodronate' [All Fields]) OR 'Clodronic acid' [All Fields] OR ('tiludronic acid' [Supplementary Concept] OR 'tiludronic acid’ [All Fields] OR
40

Horm Res Paediatr 2015;84:26-42 DOI: $10.1159 / 000381713$
Rijks/Bongers/Vlemmix/Boot/van Dijk/ Sakkers/van Brussel 
'tiludronate' [All Fields]) OR 'Tiludronic acid' [All Fields] OR ('pamidronate' [Supplementary Concept] OR 'pamidronate'[All Fields]) OR 'pamidronic acid' [All Fields] OR ('6-amino-1-hydroxyhexane-1,1-diphosphonate' [Supplementary Concept] OR '6-amino-1-hydroxyhexane-1,1-diphosphonate' [All Fields] OR 'neridronate' [All Fields]) OR 'Neridronic acid' [All Fields] OR ('olpadronic acid' [Supplementary Concept] OR 'olpadronic acid' [All Fields] OR 'olpadronate' [All Fields]) OR 'Olpadronic acid' [All Fields] OR ('alendronate' [MeSH Terms] OR 'alendronate' [All Fields]) OR 'Alendronic acid' [All Fields] OR ('ibandronic acid'[Supplementary Concept] OR 'ibandronic acid' [All Fields] OR 'ibandronate' [All Fields]) OR 'Ibandronic acid' [All Fields] OR ('risedronic acid' [Supplementary Concept] OR 'risedronic acid' [All Fields] OR 'risedronate' [All Fields]) OR 'Risedronic acid' [All Fields] OR ('zoledronic acid'[Supplementary Concept] OR 'zoledronic acid' [All Fields] OR 'zoledronate' [All Fields]) OR 'Zoledronic acid' [All Fields]).

\section{Search String Embase}

(('osteogenesis imperfecta'/exp OR 'osteogenesis imperfecta') OR 'brittle bone disease' OR 'lobstein disease' OR 'fragilitas ossium') AND ('bisphosphonic acid derivative'/exp OR alendronate OR bisphosphonates OR bisphosphonate OR etidronate OR clodronate OR tiludronate OR pamidronate OR neridronate OR olpadronate OR ibandronate OR risedronate OR zoledronate).

\section{References}

1 Castillo H, Samson-Fang L: Effects of bisphosphonates in children with osteogenesis imperfecta: an AACPDM systematic review. Dev Med Child Neurol 2009;51:17-29.

$\checkmark 2$ Forlino A, Cabral WA, Barnes AM, Marini JC: New perspectives on osteogenesis imperfecta. Nat Rev Endocrinol 2011;7:540-557.

-3 Bishop N: Characterising and treating osteogenesis imperfecta. Early Hum Dev 2010;86: 743-746.

- 4 Takken T, Terlingen HC, Helders PJ, Pruijs $\mathrm{H}$, van der Ent CK, Engelbert RH: Cardiopulmonary fitness and muscle strength in patients with osteogenesis imperfecta type I. J Pediatr 2004;145:813-818.

-5 van Brussel M, Takken T, Uiterwaal CS, Pruijs HJ, van der Net J, Helders PJ, et al: Physical training in children with osteogenesis imperfecta. J Pediatr 2008;152:111-116, 116.e1.

6 Cole WG: Advances in osteogenesis imperfecta. Clin Orthop Relat Res 2002:6-16.

7 Engelbert RHH, van Brussel M, Rameckers EAA, Shapiro JR: Functional outcomes measures in children with osteogenesis imperfecta; in Shapiro JR, Byers PH, Glorieux FH, Sponseller PD (eds): Osteogenesis Imperfecta: a Translational Approach to Brittle Bone Disease. London, Elsevier, 2014, p 555.

8 Cundy T: Recent advances in osteogenesis imperfecta. Calcif Tissue Int 2012;90:439449.

-9 Zeitlin L, Fassier F, Glorieux FH: Modern approach to children with osteogenesis imperfecta. J Pediatr Orthop B 2003;12:77-87.

10 Byers PH: Osteogenesis imperfecta: perspectives and opportunities. Curr Opin Pediatr 2000;12:603-609.

11 Rauch F, Glorieux FH: Osteogenesis imper fecta. Lancet 2004;363:1377-1385.

-12 Monti E, Mottes M, Fraschini P, Brunelli P, Forlino A, Venturi G, et al: Current and emerging treatments for the management of osteogenesis imperfecta. Ther Clin Risk Manag 2010;6:367-381.
13 Phillipi CA, Remmington T, Steiner RD: Bisphosphonate therapy for osteogenesis imperfecta. Cochrane Database Syst Rev 2008; 4:CD005088.

14 Antoniazzi F, Monti E, Venturi G, Franceschi $\mathrm{R}$, Doro F, Gatti D, et al: GH in combination with bisphosphonate treatment in osteogenesis imperfecta. Eur J Endocrinol 2010;163: 479-487.

$\checkmark 15$ Maruotti N, Corrado A, Neve A, Cantatore FP: Bisphosphonates: effects on osteoblast. Eur J Clin Pharmacol 2012;68:1013-1018.

16 Fleisch H: Bisphosphonates in osteoporosis. Eur Spine J 2003;12:S142-S146.

17 Sakkers R, Kok D, Engelbert R, van Dongen A, Jansen M, Pruijs H, et al: Skeletal effects and functional outcome with olpadronate in children with osteogenesis imperfecta: a 2 -year randomised placebo-controlled study. Lancet 2004;363:1427-1431.

18 Gatti D, Viapiana O, Lippolis I, Braga V, Prizzi R, Rossini M, et al: Intravenous bisphosphonate therapy increases radial width in adults with osteogenesis imperfecta. J Bone Miner Res 2005;20:1323-1326.

19 Letocha AD, Cintas HL, Troendle JF, Reynolds JC, Cann CE, Chernoff EJ, et al: Controlled trial of pamidronate in children with types III and IV osteogenesis imperfecta confirms vertebral gains but not short-term functional improvement. J Bone Miner Res 2005; 20:977-986.

20 Seikaly MG, Kopanati S, Salhab N, Waber P, Patterson D, Browne R, et al: Impact of alendronate on quality of life in children with osteogenesis imperfecta. J Pediatr Orthop 2005; 25:786-791.

21 Antoniazzi F, Zamboni G, Lauriola S, Donadi L, Adami S, Tato L: Early bisphosphonate treatment in infants with severe osteogenesis imperfecta. J Pediatr 2006;149:174-179.

22 Rauch F, Munns C, Land C, Glorieux FH: Pamidronate in children and adolescents with osteogenesis imperfecta: effect of treatment discontinuation. J Clin Endocrinol Metab 2006;91:1268-1274.
23 Dimeglio LA, Ford L, McClintock C, Peacock $\mathrm{M}$ : A comparison of oral and intravenous bisphosphonate therapy for children with osteogenesis imperfecta. J Pediatr Endocrinol Metab 2005; 18:43-53.

24 DiMeglio LA, Peacock M: Two-year clinical trial of oral alendronate versus intravenous pamidronate in children with osteogenesis imperfecta. J Bone Miner Res 2006;21:132140 .

25 Arikoski P, Silverwood B, Tillmann V, Bishop $\mathrm{NJ}$ : Intravenous pamidronate treatment in children with moderate to severe osteogenesis imperfecta: assessment of indices of dual-energy X-ray absorptiometry and bone metabolic markers during the first year of therapy. Bone 2004:34:539-546.

26 Falk MJ, Heeger S, Lynch KA, DeCaro KR, Bohach D, Gibson KS, et al: Intravenous bisphosphonate therapy in children with osteogenesis imperfecta. Pediatrics 2003;111: 573-578.

27 DiMeglio LA, Ford L, McClintock C, Peacock M: Intravenous pamidronate treatment of children under 36 months of age with osteogenesis imperfecta. Bone 2004;35:1038-1045.

28 Forin V, Arabi A, Guigonis V, Filipe G, Bensman A, Roux C: Benefits of pamidronate in children with osteogenesis imperfecta: an open prospective study. Joint Bone Spine 2005; 72:313-318.

29 van Tulder MW, Suttorp M, Morton S, Bouter LM, Shekelle P: Empirical evidence of an association between internal validity and effect size in randomized controlled trials of low-back pain. Spine (Phila Pa 1976) 2009;34: 1685-1692.

30 Landis JR, Koch GG: The measurement of observer agreement for categorical data. Biometrics 1977;33:159-174.

-31 Gatti D, Antoniazzi F, Prizzi R, Braga V, Rossini M, Tato L, et al: Intravenous neridronate in children with osteogenesis imperfecta: a randomized controlled study. J Bone Miner Res 2005;20:758-763. 
-32 Bishop N, Adami S, Ahmed SF, Anton J, Arundel P, Burren CP, et al: Risedronate in children with osteogenesis imperfecta: a randomised, double-blind, placebo-controlled trial. Lancet 2013;382:1424-1432.

33 Rauch F, Munns CF, Land C, Cheung M, Glorieux FH: Risedronate in the treatment of mild pediatric osteogenesis imperfecta: a randomized placebo-controlled study. J Bone Miner Res 2009;24:1282-1289.

- 34 Ward LM, Rauch F, Whyte MP, D'Astous J, Gates PE, Grogan D, et al: Alendronate for the treatment of pediatric osteogenesis imperfecta: a randomized placebo-controlled study. J Clin Endocrinol Metab 2011;96:355-364.

- 35 Li M, Xia W, Xing X, Yu W, Hu Y, Jiang Y, et al: Benefit of infusions with ibandronate treatment in children with osteogenesis imperfecta. Chin Med J 2011;124:3049-3053.

-36 Land C, Rauch F, Glorieux FH: Cyclical intravenous pamidronate treatment affects metaphyseal modeling in growing patients with osteogenesis imperfecta. J Bone Miner Res 2006;21:374-379.

37 Land C, Rauch F, Montpetit K, Ruck-Gibis J, Glorieux FH: Effect of intravenous pamidronate therapy on functional abilities and level of ambulation in children with osteogenesis imperfecta. J Pediatr 2006;148:456-460.
38 Land C, Rauch F, Munns CF, Sahebjam S, Glorieux FH: Vertebral morphometry in children and adolescents with osteogenesis imperfecta: effect of intravenous pamidronate treatment. Bone 2006;39:901-906.

39 Dwan K, Phillipi CA, Steiner RD, Basel D: Bisphosponate therapy for osteogenesis imperfecta. Cochrane Database Syst Rev 2014; 7:CD005088.

40 Nicolaou N, Agrawal Y, Padman M, Fernandes JA, Bell MJ: Changing pattern of femoral fractures in osteogenesis imperfecta with prolonged use of bisphosphonates. J Child Orthop 2012;6:21-27.

41 Whyte M, Wenker D, Clements K, McAlister W, Mumm S: Bisphosphonate-induced osteopetrosis. N Engl J Med 2003;349:457-463.

42 Goulding A, Jones IE, Taylor RW, Manning PJ, Williams SM: More broken bones: a 4-year double cohort study of young girls with and without distal forearm fractures. J Bone Miner Res 2000;15:2011-2018.

43 Clark EM, Ness AR, Bishop NJ, Tobias JH: Association between bone mass and fracture in children: a prospective cohort study. J Bone Min Res 2006;21:1489-1495.

44 Pazianas M, Abrahamsen B: Safety of bisphosphonates. Bone 2011;49:103-110.

45 Glorieux FH, Bishop NJ, Plotkin H, Chabot G, Lanoue G, Travers R: Cyclic administration of pamidronate in children with severe osteogenesis imperfecta. N Engl J Med 1998;339: 947-952.
46 Astrom E, Soderhall S: Beneficial effect of bisphosphonate during five years of treatment of severe osteogenesis imperfecta. Acta Paediatr 1998;87:64-68.

47 Banerjee I, Shortland GJ, Evans WD, Gregory JW: Osteogenesis imperfecta and intravenous pamidronate. Arch Dis Child 2002;87:562563.

48 Plotkin H, Rauch F, Bishop NJ, Montpetit K, Ruck-Gibis J, Travers R, et al: Pamidronate treatment of severe osteogenesis imperfecta in children under 3 years of age. J Clin Endocrinol Metab 2000;85:1846-1850.

49 Dunn C, Goa K: Risodronate: A review of its pharmacological properties and clinical use in resorptive bone disease. Drugs 2001;61:685712

50 Degrossi O, Ortiz M, Degrossi E, Garcia de Rio H, Barreira J, Messina D, et al: Serum Kinetics, biovariability and bone scanning of $9 \mathrm{mmTc}$-labelled sodium olpadronate in patients with different rates of bone turnover. Eur J Clin Pharmacol 1995;48:489-494.

51 Land C, Rauch F, Travers R, Glorieux FH: Osteogenesis imperfecta type VI in childhood and adolescence: effects of cyclical intravenous pamidronate treatment. Bone 2007;40: 638-644. 